\title{
Intra-annual variability of carbon and nitrogen stable isotopes in suspended organic matter in waters of the western continental shelf of India
}

\author{
M. V. Maya, S. G. Karapurkar, H. Naik, R. Roy, D. M. Shenoy, and S. W. A. Naqvi \\ National Institute of Oceanography (Council for Scientific and Industrial Research), Dona Paula, Goa-403004, India
}

Received: 5 April 2011 - Published in Biogeosciences Discuss.: 18 April 2011

Revised: 9 November 2011 - Accepted: 11 November 2011 - Published: 28 November 2011

\begin{abstract}
Intra-annual variations of $\delta^{13} \mathrm{C}$ and $\delta^{15} \mathrm{~N}$ of watercolumn suspended particulate organic matter (SPOM) have been investigated to understand the biogeochemical cycling of $\mathrm{C}$ and $\mathrm{N}$ in the Western Continental Shelf of India (WCSI). The key issues being addressed are: how the $\delta^{15} \mathrm{~N}$ of SPOM is affected by seasonally varying processes of organic matter production and respiration and how it relates to the $\delta^{15} \mathrm{~N}$ of sedimentary organic matter that appears to show a decreasing trend despite an apparent intensification of seasonal oxygen deficiency over the past few decades? A secondary objective was to evaluate the sources of organic carbon. Elemental carbon and nitrogen concentrations, $\mathrm{C} / \mathrm{N}$ ratios in SPOM, along with ancillary chemical and biological variables including phytoplankton pigment abundance were also determined on a seasonal basis (from March 2007 to September 2008), with the partial exception of the southwest (SW) monsoon period. The results reveal significant shifts in isotopic signatures, especially $\delta^{15} \mathrm{~N}$, of SPOM before and after the onset of SW monsoon. Very low $\delta^{15} \mathrm{~N}$ values, reaching a minimum of $-4.17 \%$, are found during the pre-monsoon period. Our results provide the first direct evidence for the addition of substantial amounts of isotopically light nitrogen by the diazotrophs, especially Trichodesmium, in the region. The $\delta^{15} \mathrm{~N}$ of SPOM is generally lower than the mean value $(7.38 \%$ ) for surficial sediments, presumably because of diagenetic enrichment. The results support the view that sedimentary $\delta^{15} \mathrm{~N}$ may not necessarily reflect denitrification intensity in the overlying waters due to diverse sources of nitrogen and variability of its isotopic composition. The observed intra-annual variability of $\delta^{13} \mathrm{C}$ of SPOM during the pre-monsoon and post-monsoon periods is generally small. Phytoplankton production and probably species composition could drive some of the observed changes. The largest changes (depletion of
\end{abstract}

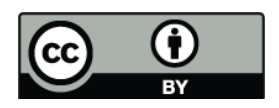

Correspondence to: M. V. Maya (mmayae11@gmail.com) $\delta^{13} \mathrm{C}$ and increase in $\mathrm{C} / \mathrm{N}$ ) appear to occur during the preand post-monsoon seasons, presumably through episodic deposition of terrestrial organic matter from the atmosphere. During the SW monsoon, when a large input of terrestrial organic matter is expected through runoff from land, the $\mathrm{C} / \mathrm{N}$ ratio remains low, but significant difference is observed between $\delta^{13} \mathrm{C}$ data in 2007 and 2008. Inputs of soil organic matter that may have elemental and isotopic signatures different from those of the conventional $\left(\mathrm{C}_{3}\right.$ plant derived) organic matter could explain the constancy of the $\mathrm{C} / \mathrm{N}$ ratio.

\section{Introduction}

Stable carbon and nitrogen isotope ratios $\left({ }^{13} \mathrm{C} /{ }^{12} \mathrm{C}\right.$ and ${ }^{15} \mathrm{~N} /{ }^{14} \mathrm{~N}$ expressed as $\delta^{13} \mathrm{C}$ and $\delta^{15} \mathrm{~N}$ with reference to the PDB (Pee Dee Belemnite) and atmospheric $\mathrm{N}_{2}$ ) in suspended particulate organic matter (SPOM) in coastal and estuarine waters have been used in numerous studies to understand sources of organic matter and its transformation pathways (Peters et al., 1978; Wada et al., 1987; Cifuentes et al., 1988; Middelburg and Nieuwenhuize, 1998). Distinction between terrestrial and autochthonous or marine sources is facilitated by their widely different isotope ratios - typical $\delta^{13} \mathrm{C}$ for land-derived organic matter, when not under the influence of $\mathrm{C}_{4}$ plants, are $-23 \%$ o to $-30 \%$ and for the organic matter produced in the sea, the ranges are $-19 \%$ to $-22 \%$ o (Smith and Epstein, 1971; Fry and Scherr, 1984; Fontugne and Jouanneau, 1987; Boutton, 1991; Riera et al., 1999; Darnaude et al., 2004). The $\delta^{15} \mathrm{~N}$ for terrestrial vascular plants ranges from $-5 \%$ to $18 \%$, whereas marine organic matter exhibits $\delta^{15} \mathrm{~N}$ values from 3\%o to $12 \%$ (Owens, 1987; Wada and Hattori, 1991; Muller and Voss, 1999; Riera et al., 1999; Maksymowska et al., 2000). However, this simple characterization of terrestrial and marine organic matter may not be always valid. For example, supply of highly degraded soil organic matter (SOM) having relatively elevated

Published by Copernicus Publications on behalf of the European Geosciences Union. 
$\delta^{13} \mathrm{C}$ and lower $\mathrm{C} / \mathrm{N}$ ratio values has been found to be a major source of sedimentary organic carbon on the Congo Fan (Holtvoeth et al., 2005). The carbon isotopic composition of organic matter produced by marine phytoplankton depends on that of the source dissolved inorganic carbon (DIC) and the isotopic fractionation factor during photosynthesis (Laws et al., 1995; Keller and Morel, 1999). The latter has been found to be a function of the concentration of dissolved carbon dioxide and the phytoplankton growth rate (Francois et al., 1993; Rau et al., 1997; Popp et al., 1998; Hofmann et al., 2000). The ${ }^{13} \mathrm{C} /{ }^{12} \mathrm{C}$ ratio also varies according to species composition primarily governed by their differential uptake of $\mathrm{HCO}_{3}^{-}$and $\mathrm{pCO}_{2}$ (Falkowski, 1991; Fogel et al., 1992) and also the food web structure (Checkley and Miller, 1989). The ${ }^{15} \mathrm{~N} /{ }^{14} \mathrm{~N}$ ratio of material produced in the sea exhibits relatively large variation due to more varied sources of reactive nitrogen and its internal cycling. Isotopic fractionation during nitrate $\left(\mathrm{NO}_{3}^{-}\right)$uptake by phytoplankton in $\mathrm{NO}_{3}^{-}$-replete surface waters leads to progressive increase in $\delta^{15} \mathrm{~N}$ with the decrease in $\mathrm{NO}_{3}^{-}$concentration (Altabet et al., 1994). Preferential reduction of $\mathrm{NO}_{3}^{-}$containing ${ }^{14} \mathrm{~N}$ also leaves the residual $\mathrm{NO}_{3}^{-}$pool enriched with ${ }^{15} \mathrm{~N}$ (Naqvi et al., 1998; Brandes et al., 1998). Consequently, the $\delta^{15} \mathrm{~N}$ of organic matter photosynthesized in surface waters overlying denitrifying zones (e.g. in the Arabian Sea) is higher than in other areas not affected by water-column denitrification (e.g. the Bay of Bengal) (Schäfer and Ittekkot, 1995; Kumar et al., 2004; Montoya and Voss, 2006). By contrast, nitrogen fixation causes minor isotopic fractionation $\left(\delta^{15} \mathrm{~N}\right.$ values close to $0 \%$ o), thereby introducing lighter nitrogen into suspended organic matter (Wada et al., 1975; Saino and Hattori, 1980; Minagawa and Wada, 1986; Saino and Hattori, 1987; Carpenter et al., 1997; Altabet, 2006). In addition to the above-mentioned processes, isotopic changes also occur during early diagenesis. Besides the kinetic isotopic fractionation during the decomposition of organic matter, biosynthesis by bacteria and preferential degradation of compounds having isotopic composition different from that of the bulk organic matter contribute to diagenetic alterations of the natural isotope abundance. In the case of the carbon isotopes, these changes are relatively small (Chen et al., 2008, and references therein). By contrast, diagenesis could significantly affect the nitrogen isotopic composition of organic matter. For example, Chen et al. (2008) reported appreciable depletion of ${ }^{15} \mathrm{~N}$ in SPOM and sediments relative to phytoplankton in the coastal area off the Pearl River mouth (South China). Such negative shift in $\delta^{15} \mathrm{~N}$ could arise from the degradation of labile compounds like amino acids that may be enriched with ${ }^{15} \mathrm{~N}$ (Benner et al., 1987; Prahl et al., 1997; Böttcher et al., 1998) or from the uptake of isotopically light nitrogen by bacteria attached to organic matter (Altabet et al., 1991; Nakatsuka et al., 1997). On the other hand, enrichment of ${ }^{15} \mathrm{~N}$ (by up to $5 \%$ ) in sedimentary organic matter relative to the sinking particles has been observed by several investigators (Möbius et al., 2010, and references therein). However, this effect, most pronounced in the deep sea, is much lower at shallow sites receiving high particulate flux (Altabet et al., 1999; Ganeshram et al., 2000). This has been observed to be the case for shallow areas in the northern Indian Ocean including the Arabian Sea as well (Gaye-Haake et al., 2005).

The information presently available from the Arabian Sea on stable carbon and nitrogen abundance in SPOM is very limited. To our knowledge the only published data set is on nitrogen isotopes by Montoya and Voss (2006). This study, confined to the open ocean, revealed consistently higher $\delta^{15} \mathrm{~N}$ values (by up to $5 \%$ o) below the surface layer and small variability with either depth or geographical location, with all values falling between 9 and $11 \%$ north of the equator. Surface-layer values were lower, but still substantially above ( $>6 \%$ o) the normal oceanic range (e.g., Altabet, 1989; Mino et al., 2002; Montoya et al., 2002). The only exception to this general trend was found in the region affected by a Trichodesmium bloom where $\delta^{15} \mathrm{~N}$ fell to $\sim 4 \%$. The regionalscale ${ }^{15} \mathrm{~N}$ enrichment in SPOM was attributed to the dominant role of denitrification in determining the isotopic composition of dissolved inorganic nitrogen that is assimilated by phytoplankton. Such enrichment has also been observed in the sinking particulate organic matter (Schäfer and Ittekkot, 1995). There has not been any investigation so far of the isotopic composition of SPOM in the eastern Arabian Sea and the results being reported here are the first of their kind from this oceanographically and biogeochemically unique part of the ocean.

The Western Continental Shelf of India (WCSI) experiences strong intra-annual changes in hydrography due to semi-annual reversals of upper ocean circulation associated with the monsoons (Schott and McCreary, 2001; Naqvi et al., 2006a, b). The southwest (SW) monsoon is particularly strong in this area. Water circulation during this period (from June to October), is typical of an oceanic eastern boundary: the surface current (the West India Coastal Current, WICC) flows equatorward, inducing moderate upwelling along the coast, which brings nutrients to the euphotic zone. A poleward undercurrent is also present just off the shelf during this season, and the water upwelling over the shelf is derived from this undercurrent (Naqvi et al., 2006a, b). This circulation, to a large extent, appears to be forced remotely rather than by local winds (McCreary et al., 1993). The remote forcing is even more important during the northeast (NE) monsoon (from December to March), when the strong poleward flowing WICC opposes the wind. This flow is associated with downwelling and consequently oligotrophic conditions over the WCSI. Due to the alternating upwelling and downwelling regimes, the region is distinguished by seasonally contrasting biogeochemical conditions. Of particular interest is the seasonal occurrence of widespread and intense oxygen $\left(\mathrm{O}_{2}\right)$ deficiency associated with the SW monsoon circulation. Three factors contribute to 
the development of this phenomenon: (1) The initial $\mathrm{O}_{2}$ content of upwelling waters is low; (2) The upwelled water gets stagnated over the shelf, in part due to weak upwelling and in part because it gets capped by a thin $(5-10 \mathrm{~m})$ fresh water lens formed as a result of intense rainfall in the coastal zone; and (3) Moderate biological production largely sustained by the upwelled nutrients supports fairly high respiration rates in subsurface waters. The subsurface waters lose all dissolved $\mathrm{O}_{2}$ by July/August, thus allowing heterotrophic bacteria to respire using $\mathrm{NO}_{3}^{-}$, converting it to molecular nitrogen and nitrous oxide (denitrification). As the $\mathrm{NO}_{3}^{-}$brought up by the upwelled water gets exhausted, usually by September/October, sulphate reduction sets in, which is evident from the appearance of hydrogen sulphide and the accumulation of ammonium $\left(\mathrm{NH}_{4}^{+}\right)$in bottom waters (Naqvi et al., 2000, 2006a, b). Oxic conditions are restored with the reversal of WICC sometime in November. The seasonal $\mathrm{O}_{2}$ deficient zone of the WCSI is different from hundreds of coastal hypoxic systems that have developed in coastal areas in the last few decades (Diaz and Rosenberg, 2008) in that it is naturally formed as opposed to most other hypoxic zones that have been produced by human activities (largely eutrophication). However, there is some evidence that the $\mathrm{O}_{2}$ deficiency in this region has also intensified recently as a result of enhanced anthropogenic nutrient loading (Naqvi et al., 2000, 2006a, b). Despite a change in the bottom-water redox conditions, sedimentary $\delta^{15} \mathrm{~N}$, an index for water-column denitrification (Altabet et al., 1995), shows a moderate decreasing trend during the past $\sim 50$ years (Agnihotri et al., 2008, 2009). The reasons of this anomaly are not well understood. The sedimentary $\delta^{15} \mathrm{~N}$ should, of course, reflect the isotopic composition of DIN. The limited data that are available show large variability $\left(\delta^{15} \mathrm{~N}=3.4-22.5 \%\right.$ o $)$ in the isotopic composition of $\mathrm{NO}_{3}^{-}$(Naqvi et al., 2006a). As stated above, there are no data on isotopic composition of SPOM to link the isotopic signatures of DIN and sedimentary organic matter. Therefore, the principal objective of the present study was to understand how the $\delta^{15} \mathrm{~N}$ of SPOM is affected by seasonally varying processes of organic matter production and respiration and how it relates to the $\delta^{15} \mathrm{~N}$ of sedimentary organic matter. While our main focus is on the nitrogen isotopic abundance, we also make use of the carbon isotope data to gain insight into the sources of organic matter. This issue is also of considerable importance as the WCSI receives large runoff from land during the SW monsoon and the associated terrestrial organic matter inputs may possibly play a role in biogeochemical cycling.

\section{Methods}

\subsection{Sampling}

Time series measurements were carried out at the Candolim Time Series (CaTS) station (aka Sta. G5), which is located

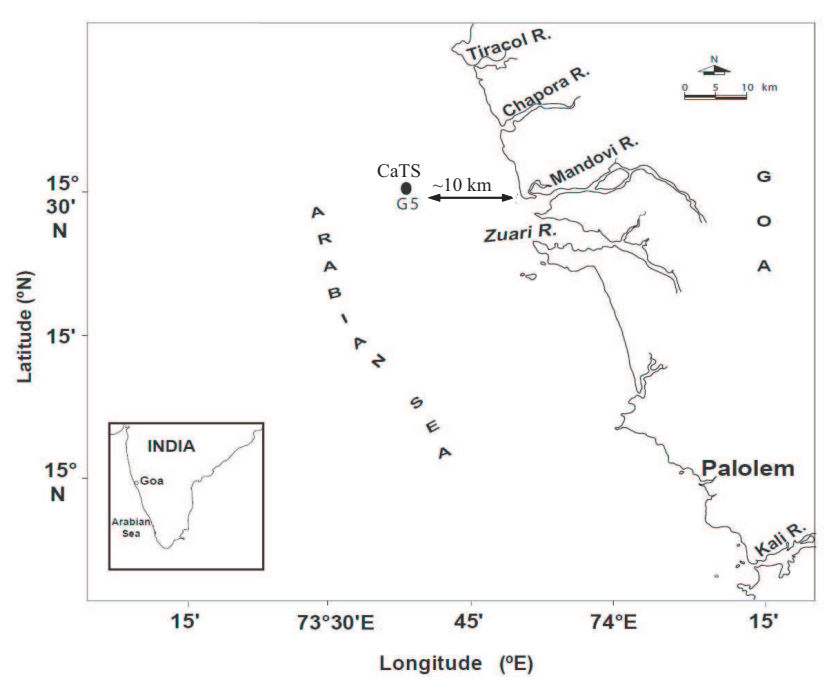

Fig. 1. Map of the study area showing the location of Candolim Time Series (CaTS) station (G5) off Goa.

at Lat. $15^{\circ} 31^{\prime} \mathrm{N}$, Long. $73^{\circ} 39^{\prime} \mathrm{E}$, approximately $10 \mathrm{~km}$ off Candolim Beach (Goa), central west coast of India (Fig. 1). We tried to sample exactly the same site during each survey using a portable global positioning system (GPS). On most occasions our point of sampling was within tens of meters of the nominal location. However, there were times when the boats used for sampling drifted a few hundred meters away from the initial position. We assume that the conditions remained similar on such a short geographical scale. The mean depth at the sampling site is $\sim 27 \mathrm{~m}$ (Fig. 1). The vertical sampling interval at CaTS is fixed since the beginning of the time series observations in 1997: samples are invariably taken from four depths - one each close to the surface and just above the seafloor and two at depths in between with equal spacing between the samples. This has been found to provide adequate vertical resolution even when the water column is strongly stratified i.e. during and shortly after the SW monsoon when the first sample usually comes from the thin mixed layer, the second from the thermocline, and the lower two from the well-mixed deeper layer. The sampling is usually done once a month depending on the logistics and weather. However, as with all time series collections there is always the question of how representative a single observation is of the entire month. We assume that despite the possible short-term temporal variability (caused, for example, by tides and local meteorological conditions), each observation provided a reasonable representation of the month.

Samples for elemental and isotopic analyses of SPOM were collected during March 2007-September 2008 covering almost all months except June-August 2007 and June-July 2008 when the sea was too rough to visit the site with the boats available to us. Niskin samplers (51) mounted on nylon ropes and fitted with reversing thermometers were used 
for sampling. Samples were also collected from the same casts for biological and chemical core measurements that were made following standard procedures (JGOFS, 1991). Dissolved $\mathrm{O}_{2}$ was estimated following the Winkler titrimetric method (Grasshoff et al., 1983) with a precision of $<1 \mu \mathrm{M}$. $\mathrm{NO}_{3}^{-}$was analyzed after reduction to nitrite $\left(\mathrm{NO}_{2}^{-}\right)$over a cadmium column and reacting with an aromatic amine to form a diazonium compound which on further reaction with a secondary aromatic amine forms an azo dye complex (Grasshoff et al., 1983). This was then quantitatively estimated using a SKALAR segmented flow analyzer with a precision of $<0.1 \mu \mathrm{M}$.

\subsection{Isotopic analytical methods}

Subsamples for the SPOM were immediately transferred to acid-cleaned plastic carboys and taken to the laboratory where they were filtered within a few hours of collection through $0.7 \mu \mathrm{m}$ pore size Whatman GF/F filters that had been precombusted at $450^{\circ} \mathrm{C}$ for $4 \mathrm{hr}$. The filters were decalcified by exposing to fumes of $\mathrm{HCl}(36 \%)$ for $12 \mathrm{hr}$ in a desiccator and later air dried in a clean laminar flow to remove all traces of acid fumes. Elemental and isotopic measurements were made on single filters. Two to three aliquots of $12 \mathrm{~mm}$ diameter were sub-sectioned from the filter paper and packed tightly in tin cups for analysis of isotopic ratios. Stable carbon and nitrogen isotope ratios were measured using a Thermo Finnigan DELTA V plus isotope ratio mass spectrometer in continuous-flow mode after high temperature flash combustion at $1050{ }^{\circ} \mathrm{C}$ in a EURO3000 Eurovector elemental analyzer (Owens and Rees, 1989) as detailed below.

Sample portions packed tightly in small tin pans (size $12.5 \times 4.25 \mathrm{~mm}$ ) are loaded into an autosampler, and then dropped onto the combustion column held at $1030^{\circ} \mathrm{C}$ where flash combustion takes place in the presence of high-purity $\mathrm{O}_{2}$. The combustion products are passed through an oxidation catalyst of chromium oxide and silvered cobaltous oxide by a constant flow of 5.5 grade dry helium at a rate of $100 \mathrm{ml} \mathrm{min}^{-1}$. The gases evolved are then passed through a reduction column containing copper wires (size $4 \times 0.5 \mathrm{~mm}$ ) at $680{ }^{\circ} \mathrm{C}$ where oxides of nitrogen $\left(\mathrm{NO}, \mathrm{N}_{2} \mathrm{O}\right.$ and $\mathrm{N}_{2} \mathrm{O}_{2}$ ) are reduced to molecular nitrogen $\left(\mathrm{N}_{2}\right)$. The reduction products $\left(\mathrm{CO}_{2}, \mathrm{~N}_{2}\right.$ and $\left.\mathrm{H}_{2} \mathrm{O}\right)$ are passed through a magnesium perchlorate $\left(\mathrm{MgClO}_{4}\right)$ trap to remove water before passing through gas chromatography (GC) column. The $\mathrm{CO}_{2}$ and $\mathrm{N}_{2}$ are separated over the $\mathrm{GC}$ column maintained at $50^{\circ} \mathrm{C}$ and the helium stream containing these gases is led via a Conflow III interface into the open split of the Delta IRMS. The ${ }^{13} \mathrm{C} /{ }^{12} \mathrm{C}$ and ${ }^{15} \mathrm{~N} /{ }^{14} \mathrm{~N}$ ratios are measured in dual mode isotopic analysis i.e. $\delta^{15} \mathrm{~N}$ and $\delta^{13} \mathrm{C}$ are estimated simultaneously from the same acid pre-treated sample. It has been reported recently that the measured carbon and nitrogen contents and the $\delta^{13} \mathrm{C}$ of organic materials coming from both terrestrial and aquatic environments are dependent on the method used for pre-analysis acid-treatment (Brodie et al., 2011a, b). Significant non-linear and disproportionate variability was observed within and between three different acid treatment methods (1. acidification followed by sequential deionised water rinses; 2. acidification in silver capsules; and 3. exposure to acid vapour). Variability was also observed within and between sample materials. The fumigation method followed by us provided the least consistent results. Thus, it is possible that our results for $\delta^{13} \mathrm{C}$ may suffer from some offset, but as pre-analysis acid treatment was carried out only by the fumigation method, the magnitude of this offset cannot be quantified.

The isotopic ratios are reported in per mil notation as follows:

$$
\begin{aligned}
& \delta^{15} \mathrm{~N} \text { or } \delta^{13} \mathrm{C}(\% o)=\left[\left(R_{\text {sample }} / R_{\text {standard }}\right)-1\right] \\
& \times 1000, \text { where } R={ }^{15} \mathrm{~N} /{ }^{14} \mathrm{~N} \text { or }{ }^{13} \mathrm{C} /{ }^{12} \mathrm{C}
\end{aligned}
$$

with the standards being atmospheric $\mathrm{N}_{2}$ and Pee Dee Belemnite (PDB), respectively.

Reference tanks for $\mathrm{N}$ and $\mathrm{C}$ isotopes were filled with $\mathrm{N}_{2}(99.9995 \%)$ and $\mathrm{CO}_{2}(99.995 \%)$. The $\mathrm{N}_{2}$ was calibrated against an IAEA standard, while a working standard, $\varepsilon$-Amino-n-Caproic Acid (ACA), kindly supplied by Prof. Mark Altabet of School for Marine Sciences and Technology (SMAST), University of Massachusetts-Dartmouth, USA, was run to check the precision. Reported ACA values of $\delta^{15} \mathrm{~N}$ and $\delta^{13} \mathrm{C}$ are $4.6 \%$ and $-25.3 \%$ respectively. Standard deviation $(1 \sigma)$ for both $\delta^{13} \mathrm{C}$ and $\delta^{15} \mathrm{~N}$ was less than $0.2 \%$ (for $n=10$ samples) (Karapurkar et al., 2008). Isotopic values obtained were corrected for size effect but no correction for blank was required. The precision of analysis was checked repeatedly after every six samples by running ACA and an in-house sediment standard COD. Carbon and nitrogen contents in the samples were calculated from a calibration curve made of ACA standards ranging from 1 to $4 \mu \mathrm{M}$ for nitrogen and 6 to $24 \mu \mathrm{M}$ for carbon. The precision of the elemental analyzer was $\pm 0.1 \mu \mathrm{g}$ and the $\mathrm{C} / \mathrm{N}$ ratios were calculated as atomic ratios. The measurement of background carbon and nitrogen concentrations were below the instrument detection limit, suggesting that contamination did not contribute to any variability in the observed results.

\subsection{Pigment analysis}

For the pigment analysis, $1-21$ of water sample was immediately filtered using a GF/F filter (pore size $0.7 \mu \mathrm{m}$ ) avoiding exposure to direct light. The filter paper was stored in liquid nitrogen until analysis in the shore laboratory. Phytoplankton pigments from the frozen filter were extracted into $3 \mathrm{ml}$ of $95 \%$ acetone ( $\mathrm{v} / \mathrm{v}$ in deionized water) for $5 \mathrm{~min}$ using an ultrasonic bath $(5 \mathrm{sec}, 20 \mathrm{kHz})$ filled with ice-water. The extract was stored overnight at $-20^{\circ} \mathrm{C}$ for high performance liquid chromatography (HPLC) analysis. The extract was passed through a teflon syringe cartridge (Millipore) having a glass fiber pre acrodisc filter (pore size $0.45 \mu \mathrm{m}$, diameter 
$25 \mathrm{~mm}$ ) to remove all cellular debris. The clear extract was then collected in a $5 \mathrm{ml}$ glass vial and placed directly into the temperature controlled $\left(5^{\circ} \mathrm{C}\right)$ auto-sampler tray for HPLC analysis. The entire extraction procedure was carried out in dim light conditions and at low temperature to minimize degradation of pigments. The HPLC analysis was carried out following the method of Van Heukelem (2002) as detailed in Roy et al. (2006). The sum of 19'-hexanoyloxyfucoxanthin (19'HF), 19'-butanoyloxyfucoxanthin (19'BF), Alloxanthin (Allo) and Chlorophyll- $b$ was used to indicate the abundance of nanoflagellates. Zeaxanthin (Zea), Fucoxanthin (Fuco) and Peridinin (Per) were considered to represent cyanobacteria, diatoms and dinoflagellates, respectively.

\section{Results}

Distributions of dissolved $\mathrm{O}_{2}, \mathrm{NO}_{3}^{-}$and chlorophyll- $a$ with depth and time at the CaTS site during the period of the study are shown in Fig. 2. The observed variations of the $\mathrm{C}$ and $\mathrm{N}$ contents, $\mathrm{C} / \mathrm{N}$ ratios, $\delta^{13} \mathrm{C}$ and $\delta^{15} \mathrm{~N}$ are shown in Fig. 3, while the corresponding data for various biomarker pigments are plotted in Fig. 4. The arithmetic means of the variables for the four depths sampled (surface, $9 \mathrm{~m}, 18 \mathrm{~m}$ and $27 \mathrm{~m}$ ) are also included in Fig. 3 and Fig. 4 connected by the bold blue lines passing through the bars. The results have been grouped according to three seasons, i.e. pre-monsoon, SW monsoon and post-monsoon. As the focus of our study is on seasonal variability, in order to get the bigger picture and also taking into account the shallow depth and limited data size, we averaged data over all depths for each of the these seasons. The mean and standard deviation $(1 \sigma)$ are presented in Table 1 and 3. Data for rainfall over Goa and freshwater discharge for the Mandovi River are shown in Fig. 6.

For investigating possible covariance between various parameters, we looked for simple linear relationships. Even though one could question the rationale of linear correlations in an inherently non-linear system, a visual examination of data reveals that a linear regression would be the best option. Obviously, any covariance will be affected by potential uncertainties, especially in $\delta^{13} \mathrm{C}$ arising from the aforementioned pre-treatment for decalcification, but one could still hope to gain insights into potential sources and transformations affecting these parameters through simple linear correlations.

\subsection{Pre-monsoon/summer (late February-May)}

The water column was generally well-mixed, oxygenated and nutrient-impoverished during the pre-monsoon periods (Fig. 2a). Dissolved $\mathrm{O}_{2}$ and $\mathrm{NO}_{3}^{-}$concentrations averaged $177 \mu \mathrm{M}(n=40, \mathrm{SD} \pm 47)$ and $1.07 \mu \mathrm{M}(n=41, \mathrm{SD} \pm 2.18)$, respectively. However, the near-bottom waters were observed to lose $\mathrm{O}_{2}$ and accumulate $\mathrm{NO}_{3}^{-}$toward the end of the season, especially in 2008. The chlorophyll- $a$ concentration was generally low, averaging $411 \mathrm{ng}^{-1}(n=34, \mathrm{SD} \pm 370)$.
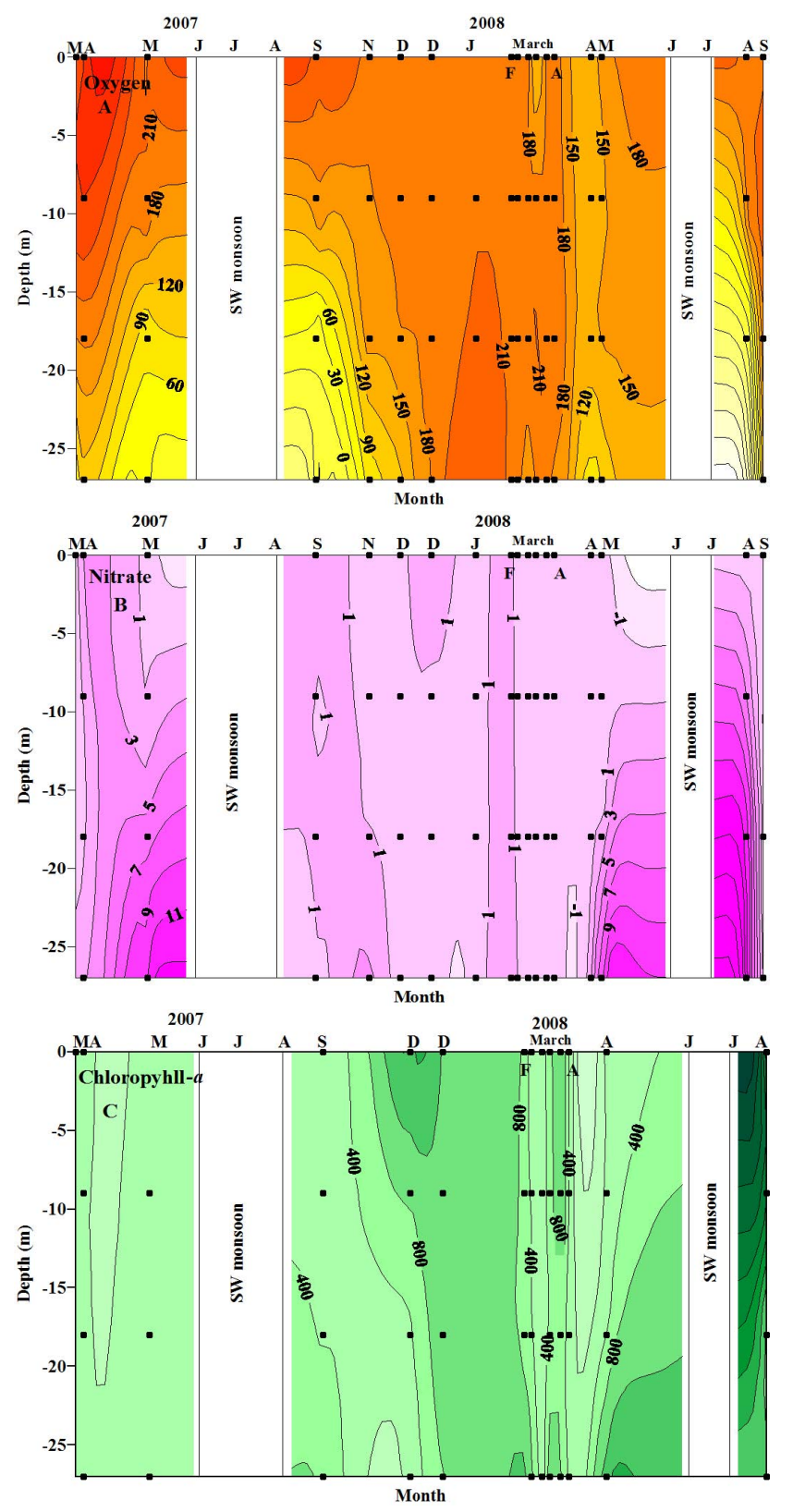

Fig. 2. Variations with depth and time in dissolved $\mathrm{O}_{2} \mu \mathrm{M}$ (A), nitrate $\mu \mathrm{M}$ (B) and chlorophyll- $a \mathrm{ng}^{-1}$ (C) at the CaTS site from March 2007 to September 2008. Note that observations could not be made during the SW monsoon due to rough weather.

The $\delta^{13} \mathrm{C}$ and $\delta^{15} \mathrm{~N}$ of the SPOM averaged $-21.40 \%$ $(n=40, \mathrm{SD} \pm 1.18 \%$ ) and $2.69 \%$ ( $n=41, \mathrm{SD} \pm 3.14 \%$ ) respectively. The overall depthwise distribution of $\delta^{13} \mathrm{C}$ did not show any significant variation between surface and bottom waters. However a decrease in $\delta^{13} \mathrm{C}$ by $3.9 \%$ in the surface water related to the bottom water occurred on 24 May 2007. A shift by $3 \%$ also occurred on 2 April 2008, and the $\mathrm{C} / \mathrm{N}$ ratio was quite different in the two cases (higher on the second occasion). The $\delta^{15} \mathrm{~N}$ showed larger decreases 


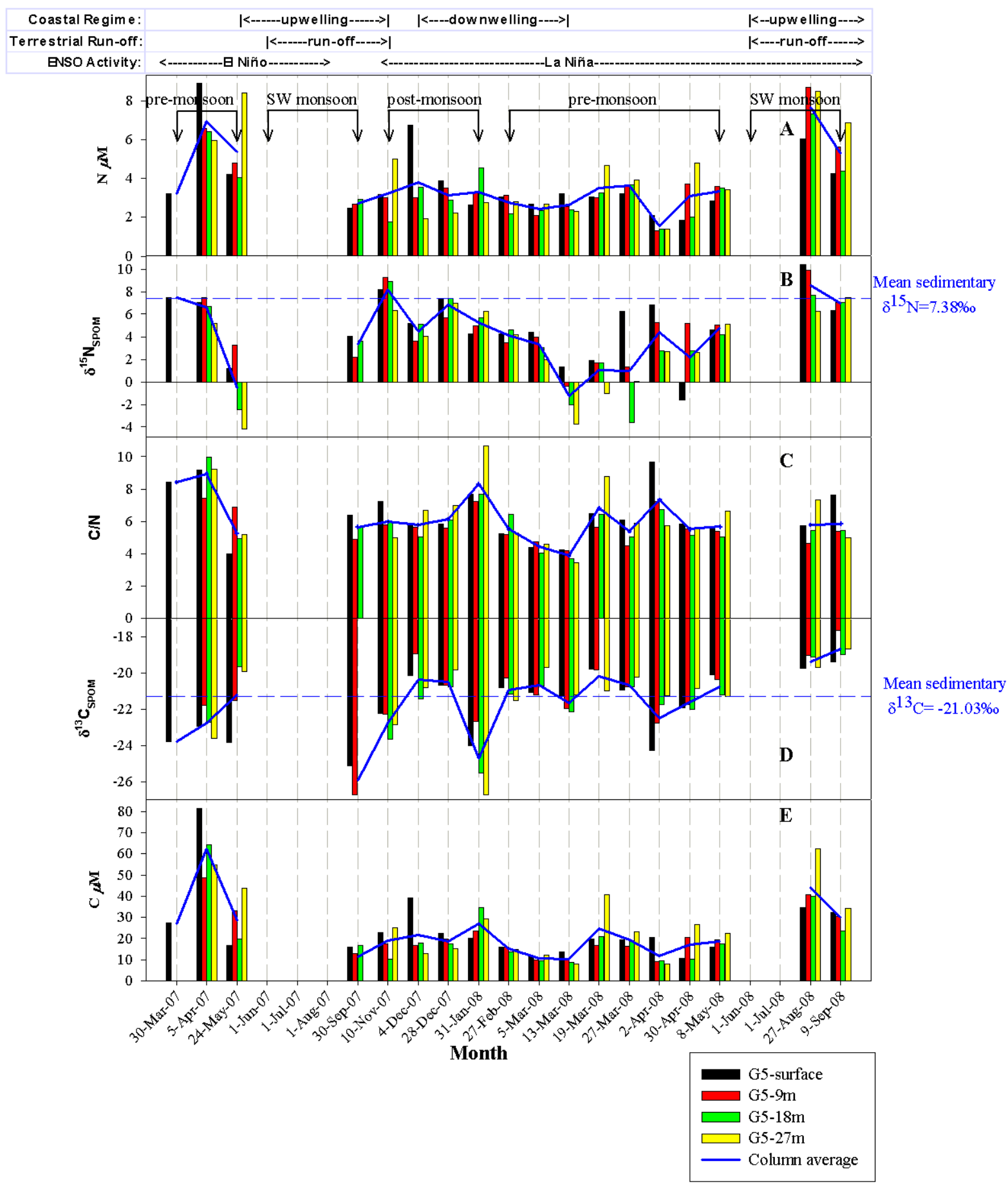

Fig. 3. Intra-annual variations of elemental nitrogen concentration $(\mathbf{A}), \delta^{15} \mathrm{~N}(\mathbf{B}), \mathrm{C} / \mathrm{N}(\mathbf{C}), \delta^{13} \mathrm{C}(\mathbf{D})$ and carbon concentration $(\mathbf{E})$ in $\mathrm{SPOM}$ at the CaTS site from March 2007 to September 2008. The three seasons (pre-monsoon, SW monsoon and post-monsoon) are marked in the figure. The bold blue line represents column-averaged values $(0 \mathrm{~m}, 9 \mathrm{~m}, 18 \mathrm{~m}$ and $27 \mathrm{~m})$ for each parameter.

from surface to bottom waters, with the values averaging $3.80 \%$ in the upper water column $(0$ and $9 \mathrm{~m}), 1.52 \%$ at $18 \mathrm{~m}$, and $0.97 \%$ close to the bottom. The $\mathrm{C} / \mathrm{N}$ ratio averaged $5.94(n=41, \mathrm{SD} \pm 1.66)$. A comparison of mean $\delta^{13} \mathrm{C}$ with the mean total chlorophyll- $a$, showed a good positive correlation $\left(r^{2}=0.68\right.$, Fig. $\left.5 \mathrm{a}\right)$ whereas a very poor correlation $\left(r^{2}=0.17\right)$ was observed between $\delta^{13} \mathrm{C}$ and $\delta^{15} \mathrm{~N}$ (Fig. 5b). The carbon content of SPOM averaged $22.0 \mu \mathrm{M}$ 

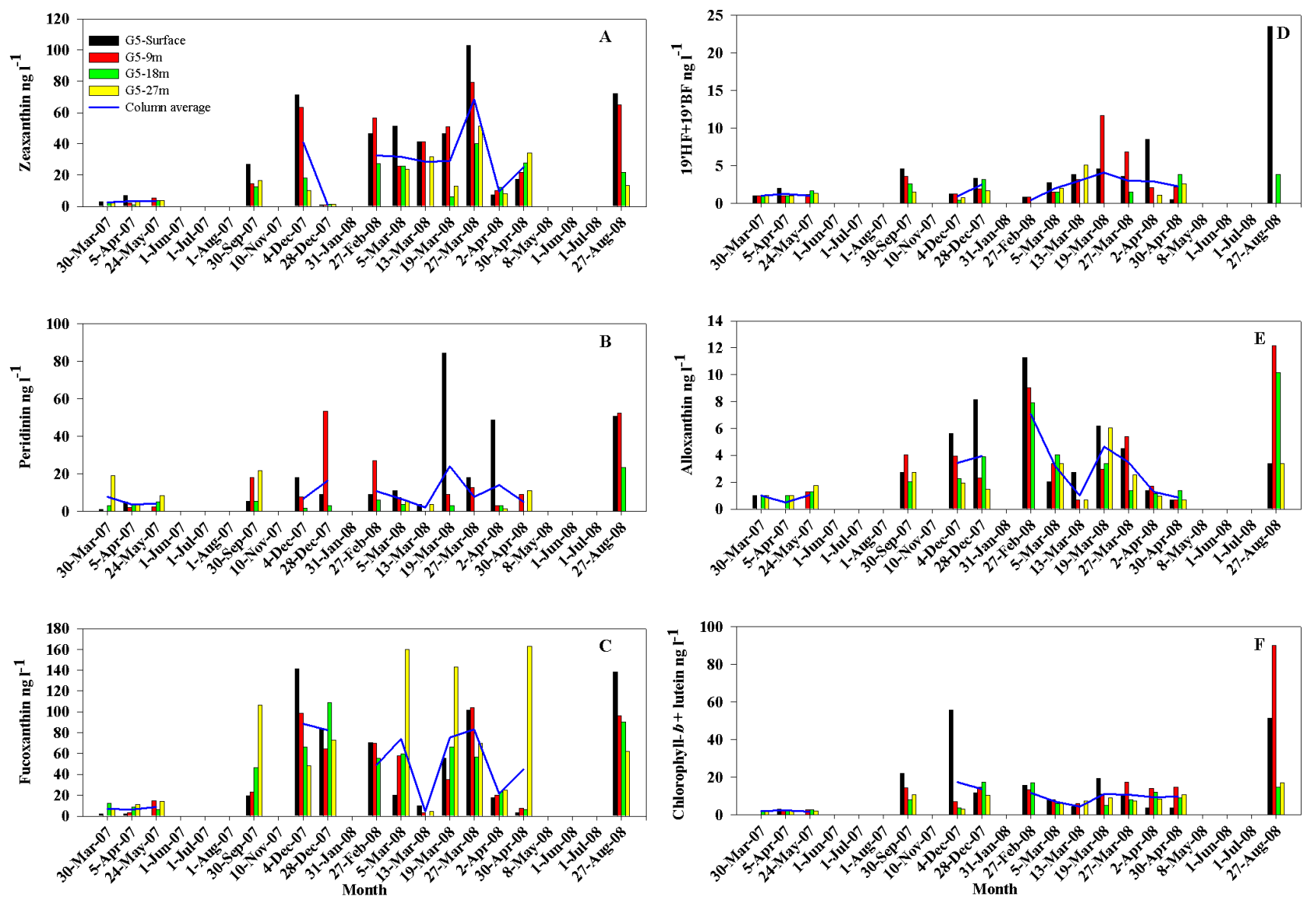

Fig. 4. Intra-annual variations of Zeaxanthin (A), Peridinin (B), Fucoxanthin (C), 19'-hexanoyloxyfucoxanthin (19'HF) + 19'butanoyloxyfucoxanthin (19'BF) (D), Alloxanthin (E), Chlorophyll- $b+$ lutein (F) at the CaTS site from March 2007 to September 2008. The bold blue line represents column-averaged values $(0 \mathrm{~m}, 9 \mathrm{~m}, 18 \mathrm{~m}$ and $27 \mathrm{~m})$ for each parameter.

( $n=41, \mathrm{SD} \pm 16.0)$ ranging widely from $8.1 \mu \mathrm{M}$ to $81.4 \mu \mathrm{M}$ with higher values observed mostly in bottom waters. The nitrogen content varied over a narrow range $(1.4-8.9 \mu \mathrm{M})$ with an average of $3.5 \mu \mathrm{M}(n=41, \mathrm{SD} \pm 1.7)$. The lowest values were observed during the first week of April 2008. A comparison of average water-column $\delta^{13} \mathrm{C}_{\mathrm{SPOM}}$ with that for the underlying surface sediments $(-21.03 \%$ ) showed only $0.37 \%$ difference, but this was not the case with $\delta^{15} \mathrm{~N}$, which was much lower (by $4.69 \%$ ) in the water-column SPOM relative to surface sediments (averaging 7.38\%o).

\subsection{SW monsoon (June-September)}

The $\mathrm{C}$ and $\mathrm{N}$ isotopic data showed distinct inter-annual variability. A comparison of the September 2007 and August/September 2008 data reveals that the $\delta^{13} \mathrm{C}$ of SPOM in the surface layer was $6.9 \%$ o heavier in 2008 than in 2007. Similarly the $\delta^{15} \mathrm{~N}$ of SPOM was on an average higher by $4.5 \%$ during the SW monsoon of 2008. A decreasing $\delta^{15} \mathrm{~N}$ trend with depth was observed during both September 2007 and August 2008; however, this trend reversed in September 2008. The inter-annual isotopic variations observed during 2007 and 2008 were also accompanied by variation in pigment distribution as well as concentrations of $\mathrm{C}$ and $\mathrm{N}$. The total chlorophyll- $a$ increased by $1582 \mathrm{ng}^{-1}$ and the $\mathrm{C}$ and $\mathrm{N}$ concentrations increased by 23 and $4 \mu \mathrm{M}$ respectively during September 2008. Accumulation of $\mathrm{NO}_{3}^{-}$up to $\sim 11 \mu \mathrm{M}$ in the bottom waters $(18-27 \mathrm{~m})$ was observed in August 2008. Dissolved $\mathrm{O}_{2}$ distribution showed a similar trend during SW monsoon of 2007 and 2008 with surface waters $(0-9 \mathrm{~m})$ being well oxygenated with the $\mathrm{O}_{2}$ concentration falling sharply in bottom waters to suboxic levels. However, a high $\mathrm{O}_{2}$ concentration $(177 \mu \mathrm{M})$ was recorded at $18 \mathrm{~m}$ during September 2008 . The $\mathrm{C} / \mathrm{N}$ ratio was as low as 4.88 at $9 \mathrm{~m}$ during September 2007 but with very low $\delta^{13} \mathrm{C}(-26.7 \%)$. The $\delta^{13} \mathrm{C}$ showed a good positive correlation with $\delta^{15} \mathrm{~N}\left(r^{2}=0.61\right.$, Fig. 5c). A correlation existed also between $\delta^{15} \mathrm{~N}$ and PON $\left(r^{2}=0.56\right.$, Fig. $\left.5 \mathrm{~d}\right)$, but $\delta^{13} \mathrm{C}$ and POC were poorly correlated $\left(r^{2}=0.37\right.$, Fig. 5 e). 
Table 1. Isotopic values $\left(\delta^{13} \mathrm{C}\right.$ and $\left.\delta^{15} \mathrm{~N}\right)$ of SPOM, their elemental $\mathrm{C}$ and $\mathrm{N}$ concentrations $(\mu \mathrm{M}), \mathrm{C} / \mathrm{N}$ ratios, $\mathrm{O}_{2}, \mathrm{NO}_{3}^{-}$and phytoplankton pigment abundance (ng $1^{-1}$ ) during pre-monsoon season at G5 station in the WCSI.

\begin{tabular}{|c|c|c|c|c|c|c|c|c|c|c|c|c|c|c|c|}
\hline Date & $\begin{array}{l}\text { Depth } \\
\text { (m) }\end{array}$ & $\begin{array}{l}\delta^{13} \mathrm{C} \\
\% o\end{array}$ & $\begin{array}{l}\delta^{15} \mathrm{~N} \\
\% o\end{array}$ & $\mathrm{C}$ & $\mathrm{N}$ & $\mathrm{C} / \mathrm{N}$ & $\mathrm{O}_{2}$ & $\mathrm{NO}_{3}$ & Zea* & Fuco* & Per* & $\begin{array}{l}19^{\prime} \mathrm{HF} \\
+ \\
19^{\prime} \mathrm{BF}^{*}\end{array}$ & $\begin{array}{l}\text { Chl- } b \\
+ \\
\text { Lutein* }\end{array}$ & Allo* & TChl- $a^{*}$ \\
\hline 30 Mar 2007 & 0 & -23.78 & 7.47 & 27.2 & 3.2 & 8.42 & 256 & 0 & 3 & 2 & 1 & 1 & 0 & 1 & 18 \\
\hline 5 Apr 2007 & $\begin{array}{l}0 \\
9 \\
18 \\
27\end{array}$ & $\begin{array}{l}-22.96 \\
-21.81 \\
-22.74 \\
-23.60\end{array}$ & $\begin{array}{l}7.01 \\
7.50 \\
6.69 \\
5.15\end{array}$ & $\begin{array}{l}81.4 \\
48.6 \\
64.2 \\
54.8\end{array}$ & $\begin{array}{l}8.9 \\
6.6 \\
6.4 \\
6.0\end{array}$ & $\begin{array}{l}9.15 \\
7.41 \\
9.99 \\
9.20\end{array}$ & $\begin{array}{l}268 \\
270 \\
198 \\
111\end{array}$ & $\begin{array}{l}2.79 \\
0.51 \\
0.26 \\
2.64\end{array}$ & $\begin{array}{l}7 \\
2 \\
1 \\
3\end{array}$ & $\begin{array}{l}2 \\
3 \\
9 \\
11\end{array}$ & $\begin{array}{l}5 \\
2 \\
4 \\
4\end{array}$ & $\begin{array}{l}2 \\
1 \\
1 \\
1\end{array}$ & $\begin{array}{l}3 \\
2 \\
2 \\
2\end{array}$ & $\begin{array}{l}0 \\
0 \\
1 \\
1\end{array}$ & $\begin{array}{l}35 \\
27 \\
27 \\
32\end{array}$ \\
\hline 24 May 2007 & $\begin{array}{l}0 \\
9 \\
18 \\
27\end{array}$ & $\begin{array}{l}-23.83 \\
-21.53 \\
-19.65 \\
-19.91\end{array}$ & $\begin{array}{l}1.21 \\
3.23 \\
-2.44 \\
-4.17\end{array}$ & $\begin{array}{l}16.7 \\
33.1 \\
19.9 \\
43.8\end{array}$ & $\begin{array}{l}4.2 \\
4.8 \\
4.0 \\
8.4\end{array}$ & $\begin{array}{l}3.97 \\
6.89 \\
4.95 \\
5.21\end{array}$ & $\begin{array}{l}207 \\
201 \\
79 \\
55\end{array}$ & $\begin{array}{l}0.95 \\
1.06 \\
4.80 \\
9.94\end{array}$ & $\begin{array}{l}5 \\
4 \\
4\end{array}$ & $\begin{array}{l}14 \\
6 \\
14\end{array}$ & $\begin{array}{l}2 \\
5 \\
8\end{array}$ & $\begin{array}{l}1 \\
2 \\
1\end{array}$ & $\begin{array}{l}3 \\
3 \\
2\end{array}$ & $\begin{array}{l}1 \\
1 \\
2\end{array}$ & $\begin{array}{l}96 \\
86 \\
153\end{array}$ \\
\hline 27 Feb 2008 & $\begin{array}{l}0 \\
9 \\
18 \\
27\end{array}$ & $\begin{array}{l}-20.82 \\
-20.27 \\
-21.15 \\
-21.51\end{array}$ & $\begin{array}{l}4.28 \\
3.49 \\
4.58 \\
4.19\end{array}$ & $\begin{array}{l}15.9 \\
16.2 \\
13.8 \\
14.7\end{array}$ & $\begin{array}{l}3.0 \\
3.1 \\
2.2 \\
2.8\end{array}$ & $\begin{array}{l}5.26 \\
5.18 \\
6.41 \\
5.30\end{array}$ & $\begin{array}{l}201 \\
201 \\
192 \\
185\end{array}$ & $\begin{array}{l}1.00 \\
0.97 \\
1.43 \\
2.32\end{array}$ & $\begin{array}{l}46 \\
57 \\
28\end{array}$ & $\begin{array}{l}71 \\
70 \\
55\end{array}$ & $\begin{array}{l}9 \\
27 \\
6\end{array}$ & $\begin{array}{l}1 \\
1 \\
0\end{array}$ & $\begin{array}{l}16 \\
13 \\
17\end{array}$ & $\begin{array}{l}11 \\
9 \\
8\end{array}$ & $\begin{array}{l}764 \\
741 \\
593\end{array}$ \\
\hline 5 Mar 2008 & $\begin{array}{l}0 \\
9 \\
18 \\
27\end{array}$ & $\begin{array}{l}-21.08 \\
-21.21 \\
-20.72 \\
-19.72\end{array}$ & $\begin{array}{l}4.37 \\
3.99 \\
3.06 \\
1.95\end{array}$ & $\begin{array}{l}11.7 \\
9.9 \\
9.6 \\
12.2\end{array}$ & $\begin{array}{l}2.7 \\
2.1 \\
2.4 \\
2.7\end{array}$ & $\begin{array}{l}4.39 \\
4.75 \\
4.06 \\
4.60\end{array}$ & $\begin{array}{l}203 \\
197 \\
188 \\
185\end{array}$ & $\begin{array}{l}0.02 \\
0.01 \\
0.19 \\
0.27\end{array}$ & $\begin{array}{l}52 \\
26 \\
26 \\
24\end{array}$ & $\begin{array}{l}20 \\
58 \\
60 \\
160\end{array}$ & $\begin{array}{l}11 \\
7 \\
4 \\
5\end{array}$ & $\begin{array}{l}3 \\
2 \\
2 \\
2\end{array}$ & $\begin{array}{l}8 \\
8 \\
6 \\
6\end{array}$ & $\begin{array}{l}2 \\
3 \\
4 \\
3\end{array}$ & $\begin{array}{l}342 \\
492 \\
472 \\
1094\end{array}$ \\
\hline 13 Mar 2008 & $\begin{array}{l}0 \\
9 \\
18 \\
27\end{array}$ & $\begin{array}{l}-21.33 \\
-21.97 \\
-22.15 \\
-21.23\end{array}$ & $\begin{array}{l}1.29 \\
-0.40 \\
-2.03 \\
-3.77\end{array}$ & $\begin{array}{l}13.8 \\
10.8 \\
8.7 \\
7.9\end{array}$ & $\begin{array}{l}3.2 \\
2.6 \\
2.4 \\
2.3\end{array}$ & $\begin{array}{l}4.26 \\
4.19 \\
3.68 \\
3.45\end{array}$ & $\begin{array}{l}197 \\
198 \\
196 \\
153\end{array}$ & $\begin{array}{l}0.01 \\
0.00 \\
0.00 \\
0.92\end{array}$ & $\begin{array}{l}41 \\
41 \\
32\end{array}$ & $\begin{array}{l}10 \\
3 \\
5\end{array}$ & $\begin{array}{l}4 \\
0 \\
4\end{array}$ & $\begin{array}{l}4 \\
3 \\
5\end{array}$ & $\begin{array}{l}4 \\
6 \\
7\end{array}$ & $\begin{array}{l}3 \\
1 \\
1\end{array}$ & $\begin{array}{l}239 \\
150 \\
\\
202\end{array}$ \\
\hline 19 Mar 2008 & $\begin{array}{l}0 \\
9 \\
18 \\
27\end{array}$ & $\begin{array}{l}-19.77 \\
-19.84 \\
-21.01\end{array}$ & $\begin{array}{l}1.92 \\
1.65 \\
1.65 \\
-1.01\end{array}$ & $\begin{array}{l}19.7 \\
16.9 \\
21.0 \\
40.8\end{array}$ & $\begin{array}{l}3.1 \\
3.0 \\
3.3 \\
4.7\end{array}$ & $\begin{array}{l}6.46 \\
5.64 \\
6.42 \\
8.76\end{array}$ & $\begin{array}{l}124 \\
208 \\
176\end{array}$ & $\begin{array}{l}0.01 \\
0.00 \\
0.09 \\
0.67\end{array}$ & $\begin{array}{l}46 \\
51 \\
6 \\
13\end{array}$ & $\begin{array}{l}56 \\
35 \\
66 \\
143\end{array}$ & $\begin{array}{l}84 \\
9 \\
3 \\
0\end{array}$ & $\begin{array}{l}5 \\
12 \\
0 \\
0\end{array}$ & $\begin{array}{l}19 \\
11 \\
5 \\
9\end{array}$ & $\begin{array}{l}6 \\
3 \\
3 \\
6\end{array}$ & $\begin{array}{l}684 \\
641 \\
456 \\
1112\end{array}$ \\
\hline 27 Mar 2008 & $\begin{array}{l}0 \\
9 \\
18 \\
27\end{array}$ & $\begin{array}{l}-20.94 \\
-20.78 \\
-20.79 \\
-20.22\end{array}$ & $\begin{array}{l}6.23 \\
1.31 \\
-3.58 \\
0.07\end{array}$ & $\begin{array}{l}19.5 \\
16.5 \\
18.5 \\
23.1\end{array}$ & $\begin{array}{l}3.2 \\
3.7 \\
3.7 \\
3.9\end{array}$ & $\begin{array}{l}6.07 \\
4.50 \\
5.02 \\
5.90\end{array}$ & $\begin{array}{l}198 \\
199 \\
198 \\
187\end{array}$ & $\begin{array}{l}0.32 \\
0.10 \\
0.10 \\
0.35\end{array}$ & $\begin{array}{l}103 \\
79 \\
40 \\
52\end{array}$ & $\begin{array}{l}102 \\
104 \\
56 \\
70\end{array}$ & $\begin{array}{l}18 \\
13 \\
0 \\
0\end{array}$ & $\begin{array}{l}4 \\
7 \\
2 \\
0\end{array}$ & $\begin{array}{l}10 \\
17 \\
8 \\
7\end{array}$ & $\begin{array}{l}5 \\
5 \\
1 \\
3\end{array}$ & $\begin{array}{l}980 \\
1012 \\
479 \\
573\end{array}$ \\
\hline 2 Apr 2008 & $\begin{array}{l}0 \\
9 \\
18 \\
27\end{array}$ & $\begin{array}{l}-24.29 \\
-22.77 \\
-21.74 \\
-21.25\end{array}$ & $\begin{array}{l}6.84 \\
5.29 \\
2.78 \\
2.70\end{array}$ & $\begin{array}{l}20.4 \\
9.2 \\
9.7 \\
8.1\end{array}$ & $\begin{array}{l}2.1 \\
1.3 \\
1.4 \\
1.4\end{array}$ & $\begin{array}{l}9.67 \\
7.21 \\
6.73 \\
5.75\end{array}$ & $\begin{array}{l}198 \\
199 \\
204 \\
172\end{array}$ & $\begin{array}{l}0.02 \\
0.00 \\
0.04 \\
0.35\end{array}$ & $\begin{array}{l}7 \\
10 \\
12 \\
8\end{array}$ & $\begin{array}{l}18 \\
20 \\
23 \\
25\end{array}$ & $\begin{array}{l}49 \\
3 \\
3 \\
1\end{array}$ & $\begin{array}{l}8 \\
2 \\
0 \\
1\end{array}$ & $\begin{array}{l}4 \\
14 \\
12 \\
8\end{array}$ & $\begin{array}{l}1 \\
2 \\
1 \\
1\end{array}$ & $\begin{array}{l}171 \\
165 \\
182 \\
230\end{array}$ \\
\hline 30 Apr 2008 & $\begin{array}{l}0 \\
9 \\
18 \\
27\end{array}$ & $\begin{array}{l}-21.93 \\
-21.74 \\
-22.01 \\
-20.86\end{array}$ & $\begin{array}{l}-1.63 \\
5.15 \\
2.76 \\
2.58\end{array}$ & $\begin{array}{l}10.9 \\
20.5 \\
10.4 \\
26.7\end{array}$ & $\begin{array}{l}1.9 \\
3.7 \\
2.0 \\
4.8\end{array}$ & $\begin{array}{l}5.85 \\
5.52 \\
5.13 \\
5.57\end{array}$ & $\begin{array}{l}139 \\
138 \\
141 \\
81\end{array}$ & $\begin{array}{l}0.14 \\
0.00 \\
0.00 \\
1.78\end{array}$ & $\begin{array}{l}18 \\
22 \\
28 \\
34\end{array}$ & $\begin{array}{l}3 \\
7 \\
6 \\
163\end{array}$ & $\begin{array}{l}0 \\
9 \\
0 \\
11\end{array}$ & $\begin{array}{l}1 \\
2 \\
4 \\
3\end{array}$ & $\begin{array}{l}4 \\
15 \\
9 \\
11\end{array}$ & $\begin{array}{l}1 \\
1 \\
1 \\
1\end{array}$ & $\begin{array}{l}96 \\
123 \\
178 \\
1334\end{array}$ \\
\hline 8 May 2008 & $\begin{array}{l}0 \\
9 \\
18 \\
27\end{array}$ & $\begin{array}{l}-20.11 \\
-20.35 \\
-21.22 \\
-21.32\end{array}$ & $\begin{array}{l}4.65 \\
5.03 \\
4.20 \\
5.11\end{array}$ & $\begin{array}{l}16.0 \\
19.3 \\
17.5 \\
22.6\end{array}$ & $\begin{array}{l}2.8 \\
3.6 \\
3.5 \\
3.4\end{array}$ & $\begin{array}{l}5.63 \\
5.40 \\
5.02 \\
6.62\end{array}$ & $\begin{array}{l}175 \\
147 \\
159 \\
101\end{array}$ & $\begin{array}{l}0.01 \\
0.10 \\
0.68 \\
9.16\end{array}$ & $\begin{array}{l}\text { No } \\
\text { Data }\end{array}$ & $\begin{array}{l}\text { No } \\
\text { Data }\end{array}$ & $\begin{array}{l}\text { No } \\
\text { Data }\end{array}$ & $\begin{array}{l}\text { No } \\
\text { Data }\end{array}$ & $\begin{array}{l}\text { No } \\
\text { Data }\end{array}$ & $\begin{array}{l}\text { No } \\
\text { Data }\end{array}$ & $\begin{array}{l}\text { No } \\
\text { Data }\end{array}$ \\
\hline Mean & & -21.40 & 2.69 & 22.0 & 3.5 & 5.94 & 177 & 1.07 & 27.4 & 43.2 & 9.2 & 2.5 & 8.0 & 2.7 & 411 \\
\hline $\mathrm{SD} \pm$ & & 1.18 & 3.14 & 16.0 & 1.7 & 1.66 & 47 & 2.18 & 24.0 & 46.1 & 16.2 & 2.6 & 5.1 & 2.6 & 370 \\
\hline
\end{tabular}

\subsection{Post-monsoon (October-January)}

Well-oxygenated conditions prevailed in the entire water column, barring the near-bottom waters early during the season (October-November), with an average $\mathrm{O}_{2}$ concentration of $177 \mu \mathrm{M}(n=14, \mathrm{SD} \pm 38)$. Nitrate levels decreased to an average of $0.68 \mu \mathrm{M}(n=16, \mathrm{SD} \pm 0.80)$ with the exception of a high value observed on 10 November 2007 at $27 \mathrm{~m}$. The chlorophyll- $a$ concentrations were moderate, averaging $844 \mathrm{ng} \mathrm{l}^{-1}(n=8, \mathrm{SD} \pm 393)$.

The $\delta^{13} \mathrm{C}$ and $\delta^{15} \mathrm{~N}$ values averaged $-22.15 \%$ o $(n=16$, $\mathrm{SD} \pm 2.08 \% \circ)$ and $6.19 \%$ ( $(n=16, \mathrm{SD} \pm 1.70 \%$ ) , respectively. The vertical distribution of $\delta^{13} \mathrm{C}$ was characterized by slightly less negative values (average $-21.5 \%$ ) than the bottom water (average $-22.7 \%$ ). Such a trend was absent in the water-column distribution of $\delta^{15} \mathrm{~N}$. The $\delta^{15} \mathrm{~N}$ values on 31 January 2008 showed enrichment with depth (surface to bottom) which seems to correlate well with the $\mathrm{NO}_{3}^{-}$ concentrations. The $\delta^{13} \mathrm{C}$ and $\delta^{15} \mathrm{~N}$ did not show any significant correlation (Fig. 5f). On average, the $\mathrm{C} / \mathrm{N}$ ratios $(6.55 \pm 1.39, n=16)$ were higher than those recorded during the pre-monsoon (5.94) and SW monsoon (5.77) seasons. The carbon content varied from $13.0 \mu \mathrm{M}$ to $39.0 \mu \mathrm{M}$, averaging $21.6 \mu \mathrm{M}(n=16, \mathrm{SD} \pm 7.6)$. The nitrogen content ranged from $1.9 \mu \mathrm{M}$ to $6.7 \mu \mathrm{M}$ with an overall average of $3.4 \mu \mathrm{M}$ $(n=16, \mathrm{SD} \pm 1.2)$. On average, the lowest nitrogen content 
Table 2. Isotopic values $\left(\delta^{13} \mathrm{C}\right.$ and $\left.\delta^{15} \mathrm{~N}\right)$ of SPOM, their elemental $\mathrm{C}$ and $\mathrm{N}$ concentrations $(\mu \mathrm{M}), \mathrm{C} / \mathrm{N}$ ratios, $\mathrm{O}_{2}, \mathrm{NO}_{3}^{-}$and phytoplankton pigment abundance (ng $1^{-1}$ ) during SW monsoon season at G5 station in the WCSI. (Overall mean and SD $(1 \sigma)$ are not used due to significant inter-annual variability.)

\begin{tabular}{|c|c|c|c|c|c|c|c|c|c|c|c|c|c|c|c|}
\hline Date & $\begin{array}{l}\text { Depth } \\
(\mathrm{m})\end{array}$ & $\begin{array}{l}\delta^{13} \mathrm{C} \\
\% o\end{array}$ & $\begin{array}{l}\delta^{15} \mathrm{~N} \\
\% o\end{array}$ & $\mathrm{C}$ & $\mathrm{N}$ & $\mathrm{C} / \mathrm{N}$ & $\mathrm{O}_{2}$ & $\mathrm{NO}_{3}$ & Zea* $^{*}$ & Fuco* & Per* & $\begin{array}{l}19^{\prime} \mathrm{HF} \\
+ \\
19^{\prime} \mathrm{BF}^{*}\end{array}$ & $\begin{array}{l}\text { Chl- } b \\
+ \\
\text { Lutein* }\end{array}$ & Allo* & TChl- $a^{*}$ \\
\hline 30 Sep 2007 & $\begin{array}{l}0 \\
9 \\
18 \\
27\end{array}$ & $\begin{array}{l}-25.11 \\
-26.74\end{array}$ & $\begin{array}{l}4.07 \\
2.19 \\
3.64\end{array}$ & $\begin{array}{l}15.8 \\
13.1 \\
16.7\end{array}$ & $\begin{array}{l}2.5 \\
2.7 \\
2.9\end{array}$ & $\begin{array}{l}6.40 \\
4.88 \\
5.69\end{array}$ & $\begin{array}{l}218 \\
164 \\
26 \\
3\end{array}$ & $\begin{array}{l}2.29 \\
0.26 \\
1.98 \\
0.80\end{array}$ & $\begin{array}{l}27 \\
14 \\
12 \\
17\end{array}$ & $\begin{array}{l}19 \\
23 \\
46 \\
107\end{array}$ & $\begin{array}{l}5 \\
18 \\
5 \\
22\end{array}$ & $\begin{array}{l}5 \\
4 \\
3 \\
2\end{array}$ & $\begin{array}{l}22 \\
14 \\
8 \\
11\end{array}$ & $\begin{array}{l}3 \\
4 \\
2 \\
3\end{array}$ & $\begin{array}{l}239 \\
287 \\
301 \\
684\end{array}$ \\
\hline 27 Aug 2008 & $\begin{array}{l}0 \\
9 \\
18 \\
27\end{array}$ & $\begin{array}{l}-19.74 \\
-19.05 \\
-19.11 \\
-19.72\end{array}$ & $\begin{array}{l}10.43 \\
9.90 \\
7.69 \\
6.22\end{array}$ & $\begin{array}{l}34.5 \\
47.4 \\
39.9 \\
62.2\end{array}$ & $\begin{array}{l}6.0 \\
10.2 \\
7.3 \\
8.5\end{array}$ & $\begin{array}{l}5.72 \\
4.66 \\
5.45 \\
7.31\end{array}$ & $\begin{array}{l}187 \\
187 \\
8\end{array}$ & $\begin{array}{l}0.23 \\
5.20 \\
10.34 \\
11.16\end{array}$ & $\begin{array}{l}72 \\
65 \\
22 \\
13\end{array}$ & $\begin{array}{l}139 \\
96 \\
90 \\
62\end{array}$ & $\begin{array}{l}51 \\
52 \\
23 \\
0\end{array}$ & $\begin{array}{l}23 \\
0 \\
4 \\
0\end{array}$ & $\begin{array}{l}51 \\
90 \\
15 \\
17\end{array}$ & $\begin{array}{l}3 \\
12 \\
10 \\
3\end{array}$ & $\begin{array}{l}2634 \\
2675 \\
1218 \\
1313\end{array}$ \\
\hline 9 Sep 2008 & $\begin{array}{l}0 \\
9 \\
18 \\
27\end{array}$ & $\begin{array}{l}-19.38 \\
-17.64 \\
-18.98 \\
-18.67\end{array}$ & $\begin{array}{l}6.32 \\
7.05 \\
7.05 \\
7.50\end{array}$ & $\begin{array}{l}32.4 \\
30.3 \\
23.7 \\
34.2\end{array}$ & $\begin{array}{l}4.3 \\
5.6 \\
4.4 \\
6.9\end{array}$ & $\begin{array}{l}7.62 \\
5.37 \\
5.45 \\
4.97\end{array}$ & $\begin{array}{l}199 \\
171 \\
99\end{array}$ & $\begin{array}{l}0.10 \\
0.10 \\
0.90\end{array}$ & $\begin{array}{l}\text { No } \\
\text { Data }\end{array}$ & $\begin{array}{l}\text { No } \\
\text { Data }\end{array}$ & $\begin{array}{l}\text { No } \\
\text { Data }\end{array}$ & $\begin{array}{l}\text { No } \\
\text { Data }\end{array}$ & $\begin{array}{l}\text { No } \\
\text { Data }\end{array}$ & $\begin{array}{l}\text { No } \\
\text { Data }\end{array}$ & $\begin{array}{l}\text { No } \\
\text { Data }\end{array}$ \\
\hline
\end{tabular}

Table 3. Isotopic values $\left(\delta^{13} \mathrm{C}\right.$ and $\left.\delta^{15} \mathrm{~N}\right)$ of SPOM, their elemental $\mathrm{C}$ and $\mathrm{N}$ concentrations $(\mu \mathrm{M}), \mathrm{C} / \mathrm{N}$ ratios, $\mathrm{O}_{2}, \mathrm{NO}_{3}^{-}$and phytoplankton pigment abundance $\left(\mathrm{ng}^{-1}\right)$ during post-monsoon season at $\mathrm{G} 5$ station in the WCSI.

\begin{tabular}{|c|c|c|c|c|c|c|c|c|c|c|c|c|c|c|c|}
\hline Date & $\begin{array}{l}\text { Depth } \\
\text { (m) }\end{array}$ & $\begin{array}{l}\delta^{13} \mathrm{C} \\
\% o\end{array}$ & $\begin{array}{l}\delta^{15} \mathrm{~N} \\
\% \circ\end{array}$ & $\mathrm{C}$ & $\mathrm{N}$ & $\mathrm{C} / \mathrm{N}$ & $\mathrm{O}_{2}$ & $\mathrm{NO}_{3}$ & Zea* & Fuco* & Per* & $\begin{array}{l}19^{\prime} \mathrm{HF} \\
+ \\
19^{\prime} \mathrm{BF}^{*}\end{array}$ & $\begin{array}{l}\text { Chl- } b \\
+ \\
\text { Lutein* }\end{array}$ & Allo* & TChl- $a^{*}$ \\
\hline 10 Nov 2007 & $\begin{array}{l}0 \\
9 \\
18 \\
27\end{array}$ & $\begin{array}{l}-22.24 \\
-22.29 \\
-23.68 \\
-22.89\end{array}$ & $\begin{array}{l}8.14 \\
9.26 \\
8.91 \\
6.30\end{array}$ & $\begin{array}{l}23.0 \\
17.3 \\
10.4 \\
24.9\end{array}$ & $\begin{array}{l}3.2 \\
3.0 \\
1.8 \\
5.0\end{array}$ & $\begin{array}{l}7.22 \\
5.79 \\
5.95 \\
4.99\end{array}$ & $\begin{array}{l}202 \\
174 \\
173 \\
73\end{array}$ & $\begin{array}{l}0.26 \\
0.70 \\
0.78 \\
3.38\end{array}$ & $\begin{array}{l}\text { No } \\
\text { Data }\end{array}$ & $\begin{array}{l}\text { No } \\
\text { Data }\end{array}$ & $\begin{array}{l}\text { No } \\
\text { Data }\end{array}$ & $\begin{array}{l}\text { No } \\
\text { Data }\end{array}$ & $\begin{array}{l}\text { No } \\
\text { Data }\end{array}$ & $\begin{array}{l}\text { No } \\
\text { Data }\end{array}$ & $\begin{array}{l}\text { No } \\
\text { Data }\end{array}$ \\
\hline 4 Dec 2007 & $\begin{array}{l}0 \\
9 \\
18 \\
27\end{array}$ & $\begin{array}{l}-20.17 \\
-18.97 \\
-21.44 \\
-21.8\end{array}$ & $\begin{array}{l}5.21 \\
3.60 \\
5.09 \\
4.04\end{array}$ & $\begin{array}{l}39.0 \\
16.9 \\
17.9 \\
13.0\end{array}$ & $\begin{array}{l}6.7 \\
3.0 \\
3.5 \\
1.9\end{array}$ & $\begin{array}{l}5.79 \\
5.63 \\
5.06 \\
6.69\end{array}$ & $\begin{array}{l}201 \\
191 \\
183 \\
118\end{array}$ & $\begin{array}{l}0.46 \\
0.37 \\
0.34 \\
0.49\end{array}$ & $\begin{array}{l}71 \\
64 \\
18 \\
10\end{array}$ & $\begin{array}{l}141 \\
99 \\
66 \\
48\end{array}$ & $\begin{array}{l}18 \\
8 \\
2 \\
0\end{array}$ & $\begin{array}{l}1 \\
1 \\
0 \\
1\end{array}$ & $\begin{array}{l}56 \\
7 \\
4 \\
3\end{array}$ & $\begin{array}{l}6 \\
4 \\
2 \\
2\end{array}$ & $\begin{array}{l}1454 \\
707 \\
410 \\
244\end{array}$ \\
\hline 28 Dec 2007 & $\begin{array}{l}0 \\
9 \\
18 \\
27\end{array}$ & $\begin{array}{l}-20.70 \\
-20.71 \\
-20.79 \\
-19.82\end{array}$ & $\begin{array}{l}7.33 \\
5.66 \\
7.39 \\
6.96\end{array}$ & $\begin{array}{l}22.6 \\
19.6 \\
17.5 \\
15.4\end{array}$ & $\begin{array}{l}3.9 \\
3.5 \\
2.9 \\
2.2\end{array}$ & $\begin{array}{l}5.81 \\
5.61 \\
6.07 \\
7.00\end{array}$ & $\begin{array}{l}203 \\
186 \\
181 \\
177\end{array}$ & $\begin{array}{l}1.64 \\
0.34 \\
0.50 \\
0.51\end{array}$ & $\begin{array}{l}1 \\
1 \\
1 \\
1\end{array}$ & $\begin{array}{l}83 \\
65 \\
109 \\
73\end{array}$ & $\begin{array}{l}9 \\
53 \\
3 \\
0\end{array}$ & $\begin{array}{l}3 \\
2 \\
3 \\
2\end{array}$ & $\begin{array}{l}12 \\
15 \\
17 \\
10\end{array}$ & $\begin{array}{l}8 \\
2 \\
4 \\
1\end{array}$ & $\begin{array}{l}1060 \\
934 \\
1134 \\
809\end{array}$ \\
\hline 31 Jan 2008 & $\begin{array}{l}0 \\
9 \\
18 \\
27\end{array}$ & $\begin{array}{l}-24.00 \\
--22.70 \\
-25.52 \\
-26.72\end{array}$ & $\begin{array}{l}4.24 \\
4.95 \\
5.68 \\
6.27\end{array}$ & $\begin{array}{l}20.1 \\
23.7 \\
34.7 \\
29.4\end{array}$ & $\begin{array}{l}2.6 \\
3.3 \\
4.5 \\
2.8\end{array}$ & $\begin{array}{l}7.66 \\
7.24 \\
7.66 \\
10.66\end{array}$ & $\begin{array}{l}214 \\
208\end{array}$ & $\begin{array}{l}0.13 \\
0.31 \\
0.20 \\
0.54\end{array}$ & $\begin{array}{l}\text { No } \\
\text { Data }\end{array}$ & $\begin{array}{l}\text { No } \\
\text { Data }\end{array}$ & $\begin{array}{l}\text { No } \\
\text { Data }\end{array}$ & $\begin{array}{l}\text { No } \\
\text { Data }\end{array}$ & $\begin{array}{l}\text { No } \\
\text { Data }\end{array}$ & $\begin{array}{l}\text { No } \\
\text { Data }\end{array}$ & $\begin{array}{l}\text { No } \\
\text { Data }\end{array}$ \\
\hline Mean & & -22.15 & 6.19 & 21.6 & 3.4 & 6.55 & 177 & 0.68 & 20.9 & 85.5 & 11.6 & 1.6 & 15.5 & 3.6 & 844 \\
\hline $\mathrm{SD} \pm$ & & 2.08 & 1.70 & 7.6 & 1.2 & 1.39 & 38 & 0.80 & 29.5 & 29.7 & 17.8 & 1.1 & 17.1 & 2.4 & 393 \\
\hline
\end{tabular}

* Zeaxanthin (Zea), Fucoxanthin (Fuco), Peridinin (Per), 19'-hexanoyloxyfucoxanthin (19'HF), 19'-butanoyloxyfucoxanthin (19'BF), Alloxanthin (Allo), Chlorophyll- $b+$ lutein (Chl- $b+$ lutein) and Total Chlorophyll- $a$ (TChl $a$ ).

was observed during pre-monsoon $(3.4 \mu \mathrm{M})$. While the average $\mathrm{N}$ content decreased from the $\mathrm{SW}$ monsoon maximum $(5.6 \mu \mathrm{M})$ by $2.2 \mu \mathrm{M}$ in post-monsoon, the $\delta^{15} \mathrm{~N}$ underwent only a slight change, decreasing by $0.36 \%$. As compared to $\delta^{15} \mathrm{~N}$, the seasonal changes observed in average $\delta^{13} \mathrm{C}$ were quite small (pre-monsoon: $-21.40 \%$, and post- monsoon: $-22.15 \%$ ).

\section{Discussion}

As described in Sect. 1, the WCSI experiences diverse physico-chemical conditions that seem to modulate carbon and nitrogen cycling as well as their isotopic signatures in SPOM. The most important physico-chemical phenomenon occurring in the region is the alternating upwelling and downwelling related to suboxic/anoxic and oxic conditions in near-bottom waters, each lasting for several months, the former from July/August to October/November and the latter during the rest of the year. In this section we relate these water-column transformations to the isotopic composition on SPOM. 

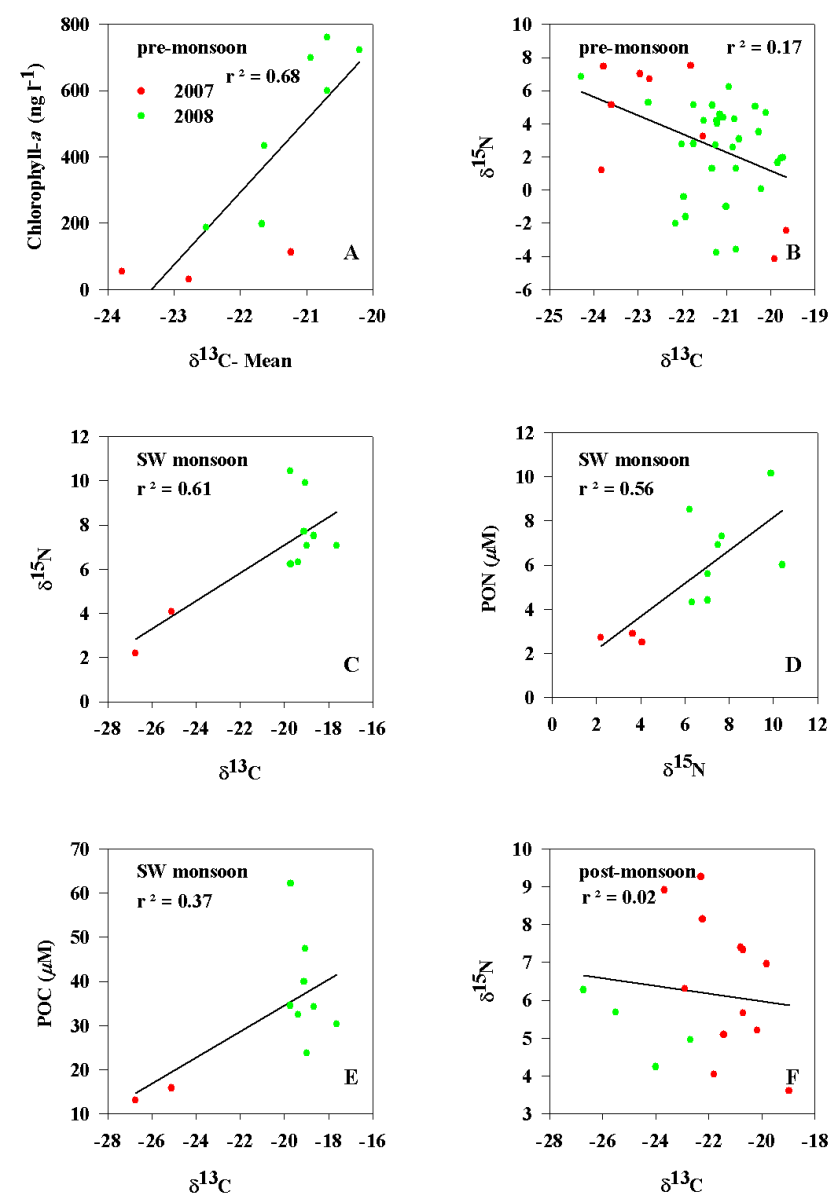

Fig. 5. (A) Correlation between mean $\delta^{13} \mathrm{C}$ and mean total chlorophyll- $a$ during pre-monsoon; (B) Correlation between $\delta^{13} \mathrm{C}$ and $\delta^{15} \mathrm{~N}$ during pre-monsoon for all data points; (C) Correlation between $\delta^{13} \mathrm{C}$ and $\delta^{15} \mathrm{~N}$ during $\mathrm{SW}$ monsoon for all data points; (D) Correlation between $\delta^{15} \mathrm{~N}$ and PON during SW monsoon for all data points; (E) Correlation between $\delta^{13} \mathrm{C}$ and POC during SW monsoon for all data points; (F) Correlation between $\delta^{13} \mathrm{C}$ and $\delta^{15} \mathrm{~N}$ during post- monsoon for all data points.

\subsection{Pre-monsoon}

During the pre-monsoon/summer season the water column at the study site remains well oxygenated (Fig. 2a). Nutrient concentrations are generally low [e.g. $\mathrm{NO}_{3}^{-}, \mathrm{NO}_{2}^{-}$, and $\mathrm{NH}_{4}^{+}$values being in the ranges $1-4 \mu \mathrm{M}, 0.5-1 \mu \mathrm{M}$ and 0 $1 \mu \mathrm{M}$, respectively (Naqvi et al., 2006b)]. Toward the end of the pre-monsoon season, however, $\mathrm{O}_{2}$ depletion and associated nutrient enrichment may sometimes occur in nearbottom waters due to an early onset of upwelling as evident by the high $\mathrm{NO}_{3}^{-}$concentration recorded by us at $27 \mathrm{~m}$ on 24 May 2007 (Fig. 2b). The $\delta^{15} \mathrm{~N}$ of SPOM during this season was found to fluctuate widely, from $-4.17 \%$ o to $7.50 \%$. Values at the lower end of this range are not commonly observed in tropical waters but comparable $\delta^{15} \mathrm{~N}$ data $(-4 \%$ o to $-5 \%$ ) have been reported from the high-nutrient, low chlorophyll (HNLC) regions such as the Southern Ocean (Altabet and Francois, 1994, 2001). Following the maximum observed during the SW monsoon-post-monsoon periods, discussed in the following sections, the $\delta^{15} \mathrm{~N}$ of SPOM decreased to $\sim 4 \%$ at the beginning of the pre-monsoon season, well below the $\delta^{15} \mathrm{~N}$ of SPOM reported from the open-ocean surface waters of the Arabian Sea (Montoya and Voss, 2006). This decrease is apparently caused by a shift in the type and/or isotopic composition of the nitrogenous nutrients used by the phytoplankton. However, a more rapid decrease in $\delta^{15} \mathrm{~N}$ occurred between 5 and 13 March 2008 to values as low as $-4.17 \%$. On the latter occasion, as also on two subsequent trips to the CaTS site, we observed large vertical gradients with the $\delta^{15} \mathrm{~N}$ values decreasing with depth. With the exception of the surface value on 27 March 2008, the $\delta^{15} \mathrm{~N}$ was consistently lower than $2 \%$ o during this period. Such low values are most probably caused by $\mathrm{N}_{2}$ fixation by cyanobacteria (Wada et al., 1975; Liu et al., 1996). The other possible explanation is the uptake of ${ }^{15} \mathrm{~N}$-depleted $\mathrm{NH}_{4}^{+}$, excreted by zooplankton, by cyanobacteria/phytoplankton (Reynolds et al., 2007). However during the pre-monsoon season, concentrations of $\mathrm{NH}_{4}^{+}$are generally quite low. In fact, the DIN as a whole is often below the detection limit, and so the latter possibility may be discounted. Blooms of nitrogen fixing Trichodesmium have long been known to occur in Indian coastal waters at this time of the year (Devassy et al., 1978). From the data collected in the present study it would appear that the bloom formation began by the end February 2008 (when minute spores appeared in water), peaked around 13 March (as inferred from the minimum $\delta^{15} \mathrm{~N}$ ) and then decayed in the following weeks as evident from the increase in $\delta^{15} \mathrm{~N}$ by $\sim 3.8 \%$. The increase in $\delta^{15} \mathrm{~N}$ during the later half, i.e. the declining phase of the bloom, indicates gradual removal of isotopically lighter nitrogen and/or inputs of isotopically heavier new nitrogen from other sources (e.g. from the sediments as the shallow water column is well-mixed during this period). Nevertheless, the $\delta^{15} \mathrm{~N}$ values remained fairly depressed during the three visits to the CaTS site in April and May 2008. The surface-water $\mathrm{NO}_{3}^{-}$concentration remained low throughout this bloom. Surprisingly, despite the lower $\delta^{15} \mathrm{~N}$, there was not much accumulation of either POC or PON, with the PON varying within a narrow range of $2-5 \mu \mathrm{M}$. It may be pointed out that while the pre-monsoon season is indeed a time of high $\mathrm{N}_{2}$ fixation, the intensity of the process probably varies substantially from year to year. The blooms could also be patchy in space and time. Thus, in 2007 low $\delta^{15} \mathrm{~N}$ values were encountered only on the last of the three samplings carried out from 30 March 2007 to 24 May 2007. The pigment data during March 2007 and 2008 also show wide variations. The preponderance of $\mathrm{N}_{2^{-}}$ fixing cyanobacteria during March 2008 is supported by data on the marker pigment Zeaxanthin, which was found to be as high as $27.4 \mathrm{ng} \mathrm{l}^{-1}$. Previous studies at this location by Roy et al. (2006) and Roy (2010) had also shown that the 
pre-monsoon season is dominated by cyanobacteria of the genus Trichodesmium.

As stated earlier, the fumigation method for decalcification followed by us yields variable $\delta^{13} \mathrm{C}$ data (Brodie et al., $2011 \mathrm{a}, \mathrm{b})$. But the $\delta^{13} \mathrm{C}$ of SPOM measured by us varied over a narrow range $(-22.96 \%$ to $-19.65 \%$ ) during the premonsoon season except for a few lighter values $(\sim-24 \%$ ) observed in 2007 and also at the surface on 2 April 2008. The lowest $\delta^{13} \mathrm{C}$ value and the second highest $\mathrm{C} / \mathrm{N}$ ratio for the pre-monsoon period observed on 2 April 2008 at the surface could result from dust input. $\mathrm{C}_{3}$ plant-derived organic compounds are common components of aerosols (Schefuß et al., 2003) with a high $\mathrm{C} / \mathrm{N}$ ratio and light isotopic value. Such input could also be significant during the 2007 premonsoon period with the exception of data taken on 24 May 2007. By and large, however, the SPOM at this site during the pre-monsoon season bears mostly the marine signature (Fry and Scherr, 1984; Fontugne and Jouanneau, 1987; Riera et al., 1999; Darnaude et al., 2004). The growth and decay of Trichodesmium were accompanied by prominent changes in $\delta^{15} \mathrm{~N}$, but did not have any significant effect on $\delta^{13} \mathrm{C}$. A good positive correlation $\left(r^{2}=0.68\right)$ between mean chlorophyll$a$ and mean $\delta^{13} \mathrm{C}$ (Fig. 5a) indicates that the observed carbon isotopic fractionation is largely due to the uptake of $\mathrm{CO}_{2}$ by phytoplankton. The $\mathrm{C} / \mathrm{N}$ ratio has long been taken to be indicative of the source (terrestrial versus marine) of the organic matter. For the material synthesized by the phytoplankton, this ratio has been reported to range from 6 to 9 (Holligan et al., 1984), whereas the terrestrial organic matter is characterized by higher $(>12) \mathrm{C} / \mathrm{N}$ (Hedges and Mann, 1979). This traditional view has been challenged by recent results. As stated earlier, highly degraded SOM may have much lower $\mathrm{C} / \mathrm{N}$ and also less negative $\delta^{13} \mathrm{C}$ (Holtvoeth et al., 2005). However, during the pre-monsoon season, when the river runoff is at its minimum (Fig. 6), the inputs of $\mathrm{SOM}$ are not expected to be significant. The average $\mathrm{C} / \mathrm{N}$ ratio observed during this season is 5.95 , lower than the Redfield value (6.6), and hence it would seem that $\mathrm{N}_{2}$-fixing Trichodesmium, which appears to have lower $\mathrm{C} / \mathrm{N}$ (Carpenter et al., 2004) may to a large extent be involved in its synthesis.

A comparison of the $\delta^{13} \mathrm{C}$ of SPOM in the water column with that of the underlying surface sediments $(-21.03 \%$ ) showed only a $0.37 \%$ difference but $\delta^{15} \mathrm{~N}$ was much lower (by $4.69 \%$ ) in the water-column SPOM relative to surface sediments (averaging 7.38\%o). The sedimentary $\delta^{15} \mathrm{~N}$ is, however, integrated over a much longer than seasonal time scale and would be determined by a combination of the isotopic composition of material being deposited on the seafloor and the diagenetic alterations that occur thereafter.

\subsection{SW monsoon}

Unfortunately, as stated earlier, we could not carry out any sampling during June-August in 2007 and June-July in 2008 due to bad weather, and so the data presented here only
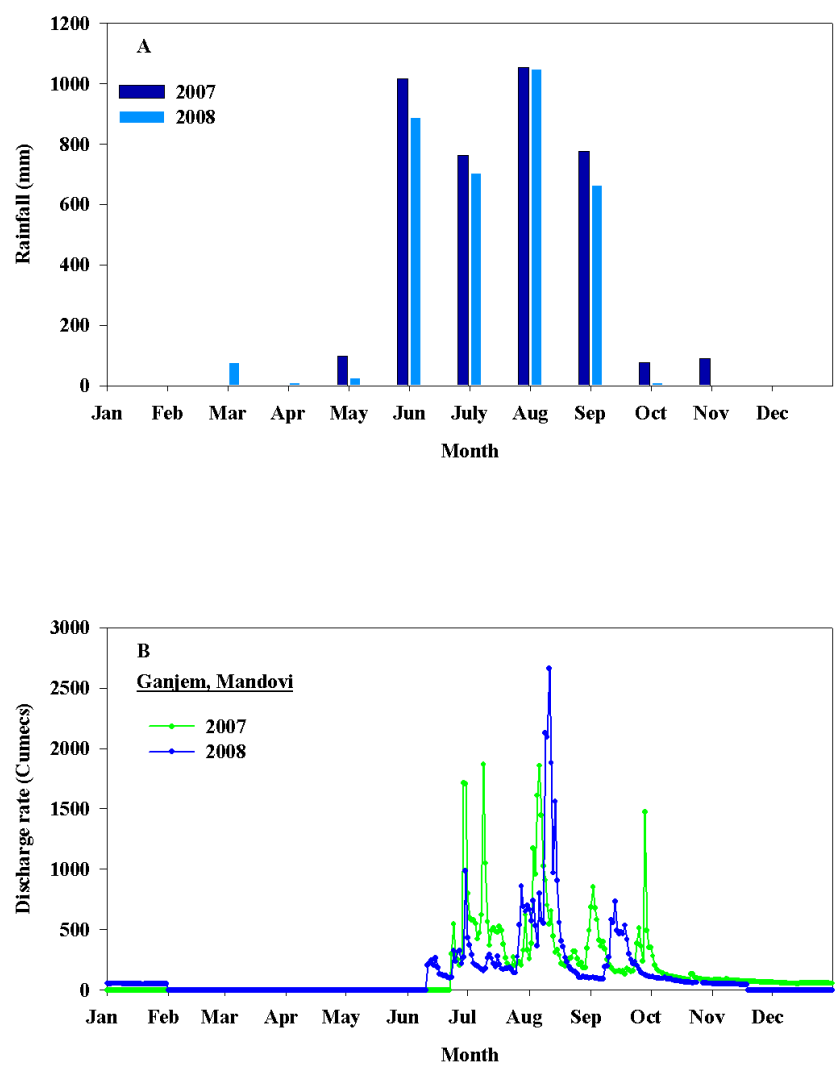

Fig. 6. (A) Monthly arithmetic average of rainfall in $\mathrm{mm}$ at Goa for the year 2007 and 2008; (B) Freshwater discharge rate at Ganjem, Mandovi estuary in cumecs or $\mathrm{m}^{3} \mathrm{~s}^{-1}$ for the year 2007 and 2008.

come from September 2007 and August 2008 onwards, representing the later part of the $\mathrm{SW}$ monsoon. The data for the two years are quite divergent in that the September 2007 measurements yielded low $(<4 \% \circ) \delta^{15} \mathrm{~N}$ values, whereas the 2008 values are among the highest observed during the entire study period, reaching as high as $\sim 10 \%$ at the surface on 27 August. The $\delta^{15} \mathrm{~N}$ on this occasion decreased with depth, a trend that reversed the next month. The high values can be easily explained by the uptake by phytoplankton from a pool of heavier $\mathrm{NO}_{3}^{-}$created by denitrification. As already pointed out, the available data on nitrogen isotopic composition of $\mathrm{NO}_{3}^{-}$from coastal waters off western India during the late $\mathrm{SW}$ monsoon shows huge variability $\left(\delta^{15} \mathrm{~N}=3.7-22.5 \%\right.$ ) (Naqvi et al., 2006a). It is hard to pin down the cause of surprisingly low $\delta^{15} \mathrm{~N}$ values of $\mathrm{NO}_{3}^{-}$in waters affected by denitrification. The various possibilities include (i) anthropogenic inputs of isotopically light nitrogen through river runoff and/or atmospheric deposition; (ii) loss of $\mathrm{NO}_{3}^{-}$through denitrification in sediments with little isotopic fractionation (Brandes and Devol, 2002); and (iii) complete loss of $\mathrm{NO}_{3}^{-}$through water-column denitrification followed by mixing with freshly upwelled water. Irrespective of the cause, the uptake of lighter DIN could have led to the low $\delta^{15} \mathrm{~N}$ of SPOM measured by us in September 2007. The 
other alternative is that the source of nitrogen also could have been different (possibly $\mathrm{NH}_{4}^{+}$produced during the anoxic decay of organic matter). It may be noted that during the periods of complete anoxic (sulphidic) conditions $\mathrm{NH}_{4}^{+}$is the dominant source of nitrogen even for the new production by the phytoplankton (Naqvi et al., 2006b). In any case, results of previous studies as well as those being reported here suggest a complex and dynamic system with large variability in the sources and isotopic composition of DIN available for phytoplankton uptake and of the organic matter produced by them.

The $\delta^{13} \mathrm{C}$ values for the $\mathrm{SW}$ monsoon of the two years are quite different. The values recorded in August-September 2008 are some of the least negative observed during the entire period of our study. Moreover, the average $\mathrm{C} / \mathrm{N}$ ratio (5.77) is also close to the marine value. This is surprising given that the runoff should add terrestrial organic matter to the region during this period (Fig. 6). One could argue that, as in the case of the Congo Fan (Holtvoeth et al., 2005), the landderived organic matter is largely SOM that cannot be easily differentiated from the marine organic matter due to relatively high $\delta^{13} \mathrm{C}$ and low $\mathrm{C} / \mathrm{N}$. But then, as pointed out above, the $\delta^{15} \mathrm{~N}$ values are quite high. It would therefore appear that the SPOM during this period was predominantly marine. The elevated $\delta^{13} \mathrm{C}$ values relative to the preceding pre-monsoon season may then be attributed to the dominance of diatoms and dinoflagellates (Fry and Wainright, 1991). The presence of these large-celled phytoplankton is supported by prominent increases in their respective marker pigments - Fucoxanthin $\left(72.8 \mathrm{ng}^{-1}\right)$ and Peridinin $\left(22 \mathrm{ng}^{-1}\right)$, respectively. Thus, there occurred a shift in phytoplankton species composition from pre-monsoon to SW monsoon (for which there is also evidence from microscopic data - Parab et al., 2006) that could possibly affect $\delta^{13} \mathrm{C}$ of SPOM, as different phytoplankton groups have different isotopic fractionation factors (Falkowski, 1991). The $\delta^{13} \mathrm{C}$ values recorded on 30 September were, by contrast, very low (down to $-26.7 \%$ ). However, the $\mathrm{C} / \mathrm{N}$ ratio was low as well (4.9). These mutually conflicting signatures cannot be explained by the inputs of terrestrial $\left(\mathrm{C}_{3}\right.$ plant derived) organic matter. Although the $\delta^{13} \mathrm{C}$ is more negative, the low $\mathrm{C} / \mathrm{N}$ value points toward the SOM origin. This may also explain the aforementioned anomalously low $\delta^{15} \mathrm{~N}$ at this time, which is well within the range $(2-5 \%$ ) reported previously for the degraded SOM (Marin-Spiotta et al., 2009).

The differences between the $\delta^{13} \mathrm{C}$ and $\delta^{15} \mathrm{~N}$ data for the two monsoons are highlighted in the correlation plots (Fig. 5c, d and e). Although a fairly good linear correlation is seen between $\delta^{13} \mathrm{C}$ and $\delta^{15} \mathrm{~N}\left(r^{2}=0.61\right.$, Fig. $\left.5 \mathrm{c}\right)$, this is mainly determined by the two values with very negative $\delta^{13} \mathrm{C}$ as well as relatively low $\delta^{15} \mathrm{~N}$ in September 2007. Similarly the correlation between $\delta^{15} \mathrm{~N}$ and PON $\left(r^{2}=0.56\right.$, Fig. $\left.5 \mathrm{~d}\right)$ also arises mainly from the low PON and low $\delta^{15} \mathrm{~N}$ data of 2007. We would also have seen a better correlation between $\delta^{13} \mathrm{C}$ and POC than actually observed $\left(r^{2}=0.37\right.$, Fig. 5e), but for the large spread of POC data in 2008. However, considering the observed inter-annual changes it is possible that the significant correlations seen in Fig. 5c and d are fortuitous.

The cause of the observed large inter-annual variability in the SW monsoon data is not entirely clear. There is some indication that the 2008 observations were made during periods when the study site was less affected by river runoff. A decrease in salinity of coastal surface waters is known to occur during the SW monsoon due to freshwater supply through the short but numerous rivers along the Indian west coast (Jayakumar et al., 2001; Suprit and Shankar, 2008). Based on the analysis of satellite data, Menon et al. (2011) showed the presence of chromophoric terrestrially-derived dissolved organic matter (CDOM) in the Mandovi estuary in response to increased river runoff during the monsoon season. These findings illustrate that during the monsoon season river-derived organic material does reach offshore areas where it might be dispersed with the coastal current. Although the overall rainfall in the region in 2007 and 2008 was comparable, its distribution was slightly different in that in 2007 the rainfall lasted longer whereas in 2008 it started earlier (Fig. 6a). This is also reflected in runoff through the Mandovi River, which was also more evenly distributed through the season in 2007 (Fig. 6b). It is tempting to attribute these differences to the different El Niño - Southern Oscillation (ENSO) conditions that prevailed during the period of our study - a weak El Niño occurred in 2006-2007, which was followed by a moderate La Niña in 2007-2008 (NOAA, 2007; NOAA, 2008). However, while several previous studies have shown a link between the ENSO events and intensity of the SW monsoon, this relationship is not very straightforward (Pant and Parthasarathy, 1981; Parthasarathy and Pant, 1985; Kripalani and Kulkarni, 1997; Maity and Kumar, 2006 and references therein).

\subsection{Post-monsoon}

The effects of SW monsoon spill over to, and indeed are sometimes more intense, during the early (OctoberNovember) post-monsoon period in terms of severe anoxia. Thus, similar to the conditions encountered during the late SW monsoon of 2008 and presumably driven by the same process (denitrification), enrichment of ${ }^{15} \mathrm{~N}$ in SPOM to a maximum of $8.15 \%$ o was noticed on 10 November 2007; also, there occurred a decrease by $2.5 \% \circ$ in $\delta^{15} \mathrm{~N}$ in bottom waters as compared to the surface and sub-surface waters with corresponding sharp increase in $\mathrm{NO}_{3}^{-}$concentrations by $2.8 \mu \mathrm{M}$ and accompanied by fall in $\mathrm{O}_{2}$ concentration by $110 \mu \mathrm{M}$. The $\delta^{15} \mathrm{~N}$ decreased thereafter and fluctuated between $3.60 \%$ and $7.39 \%$ from 4 December 2007 to 31 January 2008. After the termination of upwelling and associated anoxic conditions, other sources of nitrogen to coastal waters including sedimentary inputs and deposition of largely anthropogenic nitrogen from the atmosphere, which is maximal during the winter (Duce et al., 2008), when the wind 
blows from the northeast to the southwest, could account for the observed $\delta^{15} \mathrm{~N}$ variations.

The SPOM became progressively more enriched with ${ }^{13} \mathrm{C}$ from 10 November 2007 to 28 December 2007 (depthaveraged $\delta^{13} \mathrm{C}$ increasing from $-23.68 \%$ to $-19.26 \%$ ), but the $\mathrm{C} / \mathrm{N}$ did not vary much. This trend could be explained if the SOM that is ${ }^{13} \mathrm{C}$ depleted, but nitrogen-enriched, formed a significant fraction of SPOM during the SW monsoon of 2007. As the fraction of this SOM decreased with time and that of ${ }^{13} \mathrm{C}$-enriched marine organic matter, having $\mathrm{C} / \mathrm{N}$ similar to that of SOM, increased, the $\delta^{13} \mathrm{C}$ of the SPOM would decrease as observed from September to December 2007. In the absence of data on the composition of SOM in Goa, one could only speculate on its potential significance. Ignoring this contribution has been reported to lead to severe underestimation of terrestrial organic matter sedimentation for other tropical river systems (Holtvoeth et al., 2005; Weijers et al., 2009). In addition to the supply through runoff, presumably of SOM, favourable northeasterly winds also seem to deposit terrestrial organic matter of conventional $\left(\mathrm{C}_{3}\right.$ plant derived) composition $\left({ }^{13} \mathrm{C}\right.$ depleted and with high $\left.\mathrm{C} / \mathrm{N}\right)$. Observations on 31 January 2008 seem to provide evidence for such inputs $\left(\delta^{13} \mathrm{C}\right.$ as low as $-27 \%$ and $\mathrm{C} / \mathrm{N}$ as high as 10.66$)$. A similar event appears to have occurred subsequently on 2 April 2008, as already described in Sect. 4.1. Another possible factor that could partially contribute to the observed enrichment of ${ }^{13} \mathrm{C}$ through the post-monsoon is the change in phytoplankton species composition. Although the pigment data from our study are not sufficient to show this change, Roy (2010) reported the abundance of smaller phytoplankton groups like nanoflagellates dominated by prymnesiophytes and green algae during this period.

\section{Summary and Conclusions}

It is for the first time that the natural abundance of stable $\mathrm{C}$ and $\mathrm{N}$ isotopes in SPOM has been used as a tool to study biogeochemical processes over the western continental shelf of India, a region of global significance on account of being the largest natural seasonally-occurring coastal $\mathrm{O}_{2}$ deficient zone in the world. The results reveal large intra-annual and inter-annual variations in $\delta^{15} \mathrm{~N}$ and $\delta^{13} \mathrm{C}$ of SPOM.

Diverse external sources of nitrogen and internal cycling result in large variability of $\delta^{15} \mathrm{~N}$ of SPOM. During the oligotrophic pre-monsoon season, nitrogen fixation by Trichodesmium blooms greatly lowers the $\delta^{15} \mathrm{~N}$ of SPOM. The development of upwelling-driven suboxic/anoxic conditions in subsurface waters that result in substantial loss of nitrogen through denitrification are expected to lead to production of ${ }^{15} \mathrm{~N}$-enriched organic matter. However, the $\delta^{15} \mathrm{~N}$ of SPOM during the late SW monsoon and early post-monsoon varies over a wide range, with significant inter-annual changes. This variability may arise from the wide range of $\delta^{15} \mathrm{~N}$ of $\mathrm{NO}_{3}^{-}$, previously reported from the region, uptake of isotopically light $\mathrm{NH}_{4}^{+}$, and inputs of terrestrial organic matter (largely SOM?). Besides the lack of consistently high enrichment of ${ }^{15} \mathrm{~N}$ in SPOM during the period of intense denitrification, production of ${ }^{15} \mathrm{~N}$-depleted organic matter by diazotrophs and atmospheric deposition of isotopically light inorganic and organic nitrogen during the pre- and postmonsoon periods would also lower the $\delta^{15} \mathrm{~N}$ of SPOM, which for most parts of the year remains below the mean value $(7.38 \%$ o) for surficial sediments. The modest enrichment of ${ }^{15} \mathrm{~N}$ in sediments presumably occurs due to diagenesis despite shallow depths and seasonal prevalence of anoxia in bottom waters. Nevertheless, overall $\delta^{15} \mathrm{~N}$ values of both the SPOM and surficial sediments are below what is expected from intense seasonal denitrification in the overlying water column. The diverse processes that control the $\delta^{15} \mathrm{~N}$ of SPOM vary both intra- and inter-annually, and it is not known how the balance among them has changed over the past few decades during which an apparent intensification of seasonal $\mathrm{O}_{2}$ deficiency appears to have occurred. In any case, the water column data presented in this study support the view that sedimentary $\delta^{15} \mathrm{~N}$ is not a reliable proxy of watercolumn denitrification in the region (Agnihotri et al., 2008, 2009).

Despite the possible bias in carbon isotope data arising from the decalcification procedure (acid fumigation) followed by us, our results appear to provide interesting insights into the cycling and sources of organic carbon that need to be followed up by future studies. Overall, variations in $\delta^{13} \mathrm{C}$ and $\mathrm{C} / \mathrm{N}$ of SPOM are relatively small. Some of the observed changes could arise from phytoplankton production and probably species composition. The largest changes (low $\delta^{13} \mathrm{C}$ and high $\mathrm{C} / \mathrm{N}$ ratio) appear to occur during the pre-monsoon and post-monsoon (winter) seasons when the river discharge is low, presumably through episodic deposition of conventional $\left(\mathrm{C}_{3}\right.$ plant derived) terrestrial organic matter. During the periods of high runoff, by contrast, when a large input of terrestrial organic matter is expected, the $\mathrm{C} / \mathrm{N}$ ratios remain low although the $\delta^{13} \mathrm{C}$ exhibits substantial (inter-annual) variability that might be related to prevalence of different ENSO conditions in 2007-2008. Inputs of SOM having different $\delta^{13} \mathrm{C}$ and $\mathrm{C} / \mathrm{N}$ signatures than the conventional terrestrial organic matter could account for some of these observations.

Acknowledgements. This research was supported by the Council of Scientific and Industrial Research (CSIR), New Delhi under the projects CMM0009 and OLP0016. We gratefully acknowledge Jens Holtvoeth and an anonymous reviewer for their constructive comments on the manuscript. The authors also thank Hanumant Dalvi and B. R. Thorat for their help in field work. We also express our gratitude to the Central Water Commission (CWC) and India Meteorological Department (IMD) for making available data on freshwater discharge rate and rainfall, respectively. This is contribution No. 4960 of NIO.

Edited by: K. Suzuki 


\section{References}

Agnihotri, R., Kurian, S., Fernandes, M., Reshma, K., D’Souza, W., and Naqvi, S. W. A.: Variability of subsurface denitrification and surface productivity in the coastal eastern Arabian Sea over the past seven centuries, Holocene, 18, 755-764, 2008.

Agnihotri, R., Naqvi, S. W. A., Kurian, S., Altabet, M. A., and Bratton, J. F.: Is $\delta^{15} \mathrm{~N}$ of sedimentary organic matter a good proxy for paleodenitrification in coastal waters of the eastern Arabian Sea?, Geophys. Monogr. Ser., 185, 321-332, doi:10.1029/2008GM000770, 2009.

Altabet, M. A.: A time-series study of the vertical structure of nitrogen and particle dynamics in the Sargasso Sea, Limnol. Oceanogr., 34, 1185-1201, 1989.

Altabet, M. A.: Isotopic tracers of the marine nitrogen cycle, in: Marine organic matter: Chemical and biological markers, edited by: Volkman, J., The handbook of environmental chemistry, Springer-Verlag, 251-293, 2006.

Altabet, M. A., and Francois, R.: Sedimentary nitrogen isotopic ratio as a recorder for surface ocean nitrate utilization, Global Biogeochem. Cycle., 8, 103-116, 1994.

Altabet, M. A., and Francois, R.: Nitrogen isotope biogeochemistry of the Antarctic Polar Frontal Zone at 1701 W, Deep-Sea Res., Pt. II, 48, 4247-4273, 2001.

Altabet, M. A., Deuser, W. G., Honjo, S., and Stienen, C.: Seasonal and depth-related changes in the source of sinking particles in the North Atlantic, Nature, 354, 136-139, 1991.

Altabet, M. A., Francois, R., Murray, D. W., and Prell, W. L.: Climate related variations in denitrification in the Arabian Sea from sediment 15N/14N ratios, Nature, 373, 506-509, 1995.

Altabet, M. A., Pilskaln, C., Thunell, R., Pride, C., Sigman, D., Chavez, F., and Francois, R.: The nitrogen isotope biogeochemistry of sinking particles from the margin of the eastern North Pacific, Deep-Sea Res., Pt. I, 46, 655-679, doi:10.1016/S09670637(98)00084-3, 1999.

Benner, R., Fogel, M., Sprague, E. K., and Hodson, R. E.: Depletion of ${ }^{13} \mathrm{C}$ in lignin and its implications for stable carbon isotope studies, Nature, 329, 708-710, 1987.

Böttcher, M. E., Oelschläger, B., Höpner, T., Brumsack, H.-J., and Rullkötter, J.: Sulfate reduction related to the early diagenetic degradation of organic matter and "black spot" formation in tidal sandflats of the German Wadden Sea: stable isotope $\left({ }^{13} \mathrm{C},{ }^{34} \mathrm{~S}\right.$, $\left.{ }^{18} \mathrm{O}\right)$ and other geochemical results, Org. Geochem., 29, 15171530, 1998.

Boutton, T. W.: Stable carbon isotope ratios of natural materials: II. Atmospheric, terrestrial, marine, and freshwater environments, in: Carbon Isotopes Techniques, edited by: Coleman, D. C. and Fry, B., Academic Press Inc., San Diego, 173-185, 1991.

Brandes, J. A. and Devol, A. H.: A global marine-fixed nitrogen isotopic budget: Implications for Holocene nitrogen cycling, Global Biogeochem. Cycles., 16, 1120, doi:10.1029/2001GB001856, 2002.

Brandes, J. A., Devol, A. H., Yoshinari, T., Jayakumar, D. A., and Naqvi, S. W. A.: Isotopic composition of nitrate in the central Arabian Sea and eastern tropical North Pacific: A tracer for mixing and nitrogen cycles, Limnol. Oceanogr., 43, 1680-1689, 1998.

Brodie, C. R., Heaton, T. H. E., Leng, M. J., Casford, J. S. L., Kendrick, C. P., and Lloyd, J. M.: Evidence for bias in measured $\delta^{15} \mathrm{~N}$ values of terrestrial and aquatic organic materials due to pre-analysis acid treatment methods, Rapid Commun. Mass Spectrom., 25, 1089-1099, 2011a.

Brodie, C. R., Leng, M. J., Casford, J. S. L., Kendrick, C. K., Lloyd, J. M., Zong, Y. Q., and Bird, M. I.: Evidence for bias in C and $\mathrm{N}$ concentrations and $\delta^{13} \mathrm{C}$ composition of terrestrial and aquatic organic materials due to pre-analysis acid preparation methods, Chem. Geol., 282, 67-83, 2011b.

Carpenter, E. J., Harvey, H. R., Fry, B., and Capone, D. G.: Biogeochemical tracers of the marine cyanobacterium Trichodesmium, Deep-Sea Res. Pt. I, 44, 27-38, 1997.

Carpenter, E. J., Subramaniam, A., and Capone, D. G.: Biomass and primary productivity of the cyanobacterium Trichodesmium spp. in the tropical N Atlantic ocean, Deep-Sea Res. Pt. I, 51, 173-203, 2004.

Checkley, D. M. and Miller, C. A.: Nitrogen isotope fractionation by oceanic zooplankton, Deep-Sea Res., 36, 1449-1456, 1989.

Chen, F., Zhang, L., Yang, Y., and Zhang, D.: Chemical and isotopic alteration of organic matter during early diagenesis: Evidence from the coastal area off-shore the Pearl River estuary, south China, J. Mar. Sys., 74, 372-380, 2008.

Cifuentes, L. A., Sharp, J. H., and Fogel, M. L.: Stable carbon and nitrogen isotope biogeochemistry in the Delaware Estuary, Limnol. and Oceanogr., 33, 1102-1115, 1988.

Diaz, R. J. and Rosenberg, R.: Spreading dead zones and consequences for marine ecosystems, Science, 321, 926-929, 2008.

Darnaude, A. M., Salen-picard, C., and Harmelin-vivien, M. L.: Depth variation in terrestrial particulate organic matter exploitation by marine coastal benthic communities off the Rhone River delta (NW Mediterranean), Mar. Ecol. Prog. Ser., 275, 47-57, 2004.

Devassy, V. P., Bhattathiri, P. M. A., and Qasim, S. Z.: Trichodesmium phenomenon, Ind. J. Mar. Sci., 7, 168-186, 1978.

Duce, R. A., LaRoche, J., Altieri, K., Arrigo, K. R., Baker, A. R., Capone, D. G., Cornell, S., Dentener, F., Galloway, J., Ganeshram, R. S., Geider, R. J., Jickells, T., Kuypers, M. M., Langlois, R., Liss, P. S., Liu, S. M., Middelburg, J. J., Moore, C. M., Nickovic, S., Oschlies, A., Pedersen, T., Prospero, J., Schlitzer, R., Seitzinger, S., Sorensen, L. L., Uematsu, M., Ulloa, O., Voss, M., Ward, B., and Zamora, L.: Impacts of Atmospheric Anthropogenic Nitrogen on the Open Ocean, Science, 320, 893 897, 2008.

Falkowski, P. G.: Species variability in the fractionation of ${ }^{13} \mathrm{C}$ and ${ }^{12} \mathrm{C}$ by marine phytoplankton, J. Plankton Res., 13, 21-28, 1991.

Fogel, M. L., Cifuentes, L. A., Velinsky, D. J., and Sharp, J. H.: Relationship of carbon availability in estuarine phytoplankton to isotopic composition, Mar. Ecol. Prog. Ser., 82, 291-300, 1992.

Fontugne, M. R. and Jouanneau, J. M.: Modulation of the particulate organic carbon flux to the ocean by a macrotidal estuary evidence from measurements of carbon isotopes in organic matter from the Gironde system, Estuarine, Coastal Shelf Sci., 24, 377-387, 1987.

Francois, R., Altabet, M. A., Goericke, R., McCorkle, D. C., Brunet, C., and Poisson, A.: Changes in the $\delta^{13} \mathrm{C}$ of surface water particulate matter across the subtropical convergence in the SW Indian Ocean, Global Biogeochem. Cycles., 7, 627-64, 1993.

Fry, B. and Scherr, E. B.: $\delta^{13} \mathrm{C}$ measurements as indicators of carbon flow in marine and freshwater ecosystems, Contrib. Mar. Sci., 27, 13-47, 1984. 
Fry, B. and Wainright, S. C.: Diatom sources of ${ }^{13}$ C-rich carbon in marine food webs, Mar. Ecol. Prog. Ser., 76, 149-157, 1991.

Ganeshram, R. S., Pedersen, T. F., Calvert, S. E., McNeill, G. W., and Fontugne, M. R.: Glacial/interglacial variability in denitri?cation in the world's oceans: Causes and consequences, Paleoceanogr., 15, 361-376, 2000.

Gaye-Haake, B., Lahajnar, N., Emeis, K. C., Unger, D., Rixen, T., Suthhof, A., Ramaswamy, V., Schulz, H., Paropkari, A. L., Guptha, M. V. S., and Ittekkot, V.: Stable nitrogen isotopic ratios of sinking particles and sediments from the northern Indian Ocean, Mar. Chem., 96, 243-255, 2005.

Grasshoff, K., Ehrhardt, M., and Kremling, K.: Methods of seawater analysis, 2 Edn., 419 pp., Weinheim: Verlag Chemie., 1983.

Hedges, J. I. and Man, D. C.: The characterization of plant tissues by their lignin oxidation products, Geochim. Cosmochim. Acta., 43, 1803-1807, 1979.

Hofmann, M., Wolf-Gladrow, D. A., Takahashi, T., Sutherland, S. C., Six, K. D., and Maier-Reimer, E.: Stable carbon isotope distribution of particulate organic matter in the ocean: a model study, Mar. Chem., 72, 131-150, 2000.

Holligan, S. G., Montoya, J. P., Nevins, J. L., and McCarthy, J. J.: Vertical distribution and partitioning of organic carbon in mixed, frontal and stratified waters of the English Channel, Mar. Ecol. Prog. Ser., 14, 111-127, 1984.

Holtvoeth, J., Kolonic, S., and Wagner, T.: Soil organic matter as an important contributor to late Quaternary sediments of the tropical West African continental margin, Geochim. Cosmochim. Acta., 69, 2031-2041, 2005.

Jayakumar, D. A., Naqvi, S. W. A., Narvekar, P. V., and George, M. D.: Methane in coastal and offshore waters of the Arabian Sea, Mar. Chem., 74, 1-13, 2001.

JGOFS: JGOFS Core Measurement Protocols: Reports of the Core Measurements Working Groups, JGOFS Report No. 6, Scientific Committee on Oceanic Research, Bergen, 40 pp., 1991.

Karapurkar, S., Methar, A., and Agnihotri, R.: Measurement of C and $\mathrm{N}$ isotopes of geological samples using Delta V Plus Stable Isotope Ratio Mass Spectrometer via different preparatory systems, NIO Technical report NIO/TR-02/2008, 22 pp., 2008.

Keller, K. and Morel, F. M. M.: A model of carbon isotopic fractionation and active carbon uptake in phytoplankton, Mar. Ecol. Prog. Ser., 182, 295-298, 1999.

Kripalani, R. H. and Kulkarni, A.: Climatic impact of El Niño/La Niña on the Indian monsoon: A new perspective, Weather, 52, 39-46, 1997.

Kumar, S., Ramesh, R., Bhosle, N. B., Sardesai, S., and Sheshshayee, M. S.: Natural isotopic composition of nitrogen in suspended particulate matter in the Bay of Bengal, Biogeosciences, 1, 63-70, doi:10.5194/bg-1-63-2004, 2004.

Laws, E. A., Popp, B. N., Bidigare, R. R., Kennicutt, M. C., and Macko, S. A.: Dependence of Phytoplankton Carbon Isotopic Composition on Growth Rate and [CO2] $]_{a q}$ :Theoretical Considerations and Experimental Results, Geochim. Cosmochim. Acta., 59, 6, 1131-1138, 1995.

Liu, K.-K., Su, M.-J., Hsueh, C.-R., and Gong, G.-C.: The nitrogen isotopic composition of nitrate in the Kuroshio Water northeast of Taiwan: evidence for nitrogen fixation as a source of isotopically light nitrate, Mar. Chem., 54, 273-292, 1996.

Maity, R. and Kumar, D. N.: Bayesian dynamic modelling for monthly Indian summer monsoon rainfall using El Niño
-Southern Oscillation (ENSO) and Equatorial Indian Ocean Oscillation (EQUINOO), J. Geophys. Res., 111, D07104, doi:10.1029/2005JD006539, 2006.

Maksymowska, D., Richard, P., Piekarek-Jankowska, H., and Riera, P.: Chemical and isotopic composition of the organic matter sources in the Gulf of Gdansk (Southern Baltic Sea), Estuar. Coast. Shelf Sci., 51, 585-598, 2000.

Marin-Spiotta, E., Silver, W. L., Swanston, C. W., and Ostertag, R.: Soil organic matter dynamics during $80 \mathrm{yr}$ of reforestation of tropical pastures, Glob. Change Biol., 15, 1584-1597, doi:10.1111/j.1365-2486.2008.01805.x, 2009.

McCreary, J. P., Kundu, P. K., and Molinari, R. L.: A numerical investigation of the dynamics, thermodynamics and mixed-layer processes in the Indian Ocean, Prog. Oceanogr., 31, 181-244, 1993.

Menon, H. B., Sangekar, N. P., Lotliker, A. A., and Vethamony, P.: Dynamics of chromophoric dissolved organic matter in Mandovi and Zuari estuaries - A study through in situ and satellite data, ISPRS J. Photogramm. Remote Sens., 66, 545-552, 2011.

Middelburg, J. J. and Nieuwenhuize, J.: Carbon and nitrogen stable isotopes in suspended matter and sediments from the Schelde Estuary, Mar. Chem., 60, 217-225, 1998.

Minagawa, M. and Wada, E.: Nitrogen isotope ratios of red tide organisms in the East China Sea: a characterization of biological nitrogen fixation, Mar. Chem., 19, 245-259, 1986.

Mino, Y., Saino, T., Suzuki, K., and Maranon. E.: Isotopic composition of suspended particulate nitrogen (delta $\mathrm{N}-15$ (sus)) in surface waters of the Atlantic Ocean from 50 degrees $\mathrm{N}$ to 50 degrees S, Global Biogeochem. Cycles., 16, 1059, doi:10.1029/2001GB001635, 2002.

Möbius, J., Lahajnar, N., and Emeis, K.-C.: Diagenetic control of nitrogen isotope ratios in Holocene sapropels and recent sediments from the Eastern Mediterranean Sea, Biogeosciences, 7, 3901-3914, doi:10.5194/bg-7-3901-2010, 2010.

Montoya, J. P. and Voss, M.: Nitrogen Cycling in Anoxic Waters: Isotopic Signatures of Nitrogen Transformations in the Arabian Sea Oxygen Minimum Zone, in: NATO Science Series Book Vol. 64: Past and Present Water Column Anoxia, Proceedings of the NATO Advanced Research Workshop, held in Yalta, Crimea, Ukraine, 4-8 October 2003: 259-281, edited by: Neretin, L., 541 pp., ISBN:1-4020-4263-9, 2006.

Montoya, J. P., Carpenter, E. J., and Capone, D. G.: Nitrogen fixation and nitrogen isotope abundances in zooplankton of the oligotrophic North Atlantic, Limnol. Oceanogr., 47, 1617-1628, 2002.

Müller, A. and Voss, M.: The palaeoenvironments of coastal lagoons in the southern Baltic Sea, II. $\delta^{13} \mathrm{C}$ and $\delta^{15} \mathrm{~N}$ ratios of organic matter - sources and sediments, Palaeogeogr. Palaeoclimatol. Palaeoecol., 145, 17-32, 1999.

Nakatsuka, T., Handa, N., Sugimoto, T., and Imaizumi, S.: Origin and decomposition of sinking particulate organic matter in the deep water column inferred from the vertical distributions of its $\delta^{15} \mathrm{~N}, \delta^{\mathrm{x} 3} \mathrm{C}$ and $\delta^{14} \mathrm{C}$, Deep-Sea Res. Pt. I, 44, 1957-1979, 1997.

Naqvi, S. W. A., Yoshinari, T., Jayakumar, D. A., Altabet, M. A., Narvekar, P. V., Devol, A. H., Brandes, J. A., and Codispoti, L. A. : Budgetary and biogeochemical implications of $\mathrm{N}_{2} \mathrm{O}$ isotope signatures in the Arabian Sea, Nature, 394, 462-464, 1998.

Naqvi, S. W. A., Jayakumar, D. A., Narvekar, P. V., Naik, H., Sarma, V. V. S. S., D’Souza, W., Joseph, S., and George, M. D.: In- 
creased marine production of $\mathrm{N}_{2} \mathrm{O}$ due to intensifying anoxia on the Indian continental shelf, Nature, 408, 346-349, 2000.

Naqvi, S. W. A., Naik, H., Pratihary, A., D’Souza, W., Narvekar, P. V., Jayakumar, D. A., Devol, A. H., Yoshinari, T., and Saino, T.: Coastal versus open-ocean denitrification in the Arabian Sea, Biogeosciences, 3, 621-633, doi:10.5194/bg-3-621-2006, 2006a.

Naqvi, S. W. A., Naik, H., Jayakumar, D. A., Shailaja, M. S., and Narvekar, P. V.: Seasonal oxygen deficiency over the western continental shelf of India, in Past and Present Water- column Anoxia, NATO Science Series, IV. Earth and Environmental Sciences, edited by: Neretin, L., 64, 195-224, Springer, Dordrecht, Netherlands, 2006b.

NOAA National Climatic Data Center, State of the Climate: El Niño/Southern Oscillation Analysis for Annual 2007, published online December 2007, retrieved on November 4, 2011 from http://www.ncdc.noaa.gov/sotc/enso/2007/13.

NOAA National Climatic Data Center, State of the Climate: El Niño/Southern Oscillation Analysis for Annual 2008, published online December 2008, retrieved on November 4, 2011 from http://www.ncdc.noaa.gov/sotc/enso/2008/13.

Owens, N. J. P.: Natural variations in ${ }^{15} \mathrm{~N}$ in the marine environment, Adv. Mar. Biol., 24, 411-451, 1987.

Owens, N. J. P. and Rees, A. P.: Determination of nitrogen-15 at sub-microgram levels of nitrogen using continuous-flow isotope ratio mass spectrometry, Analyst, 114, 1655-1657, 1989.

Parab, S. G., Matondkar, S. G. P., Gomes, H., and Goes, J. I.: Monsoon driven changes in phytoplankton populations in the eastern Arabian Sea as revealed by microscopy and HPLC pigment analysis, Cont. Shelf Res., 26, 2538-2558, 2006.

Pant, G. B. and Parthasarathy, B.: Some aspect of an association between the Southern Oscillation and Indian summer monsoon, Arch. Meteorol. Geophys. Bioklimatol., Ser. B, 89, 179-195, 1981.

Parthasarathy, B. and Pant, G. B.: Seasonal relationship between Indian summer monsoon rainfall and Southern Oscillation, J. Climatol., 5, 369-378, 1985.

Peters, K. E., Sweeney, R. E., and Kaplan, I. R.: Correlation of carbon and nitrogen stable isotope ratios in sedimentary organic matter, Limnol. Oceanogr., 23, 598-604, 1978.

Popp, B. N., Laws, E. A., Bidigare, R. R., Dore, J. E., Hanson, K. L., and Wakeham, S. G.: Effect of phytoplankton cell geometry on carbon isotopic fractionation, Geochim. Cosmochim. Acta, 62, 69-77, 1998.

Prahl, F. G., de Lange, G. J., Scholten, S., and Cowie, G. L.: A case of postdepositional aerobic degradation of terrestrial organic matter in turbidite deposits from the Madeira Abyssal Plain, Organic Geochem., 27, 141-152, 1997.

Rau, G. H., Riebesell, U., and Wolf-Gladrow, D.: $\mathrm{CO}_{2(a q)^{-}}$dependent photosynthetic ${ }^{13} \mathrm{C}$ fractionation in the ocean: A model versus measurements, Global Biogeochem Cycles., 11, 267-278, 1997.

Reynolds, S. E., Mather, R. L., Wolff, G. A., Williams, R. G., Landolfi, A., Sanders, R., and Woodward, E. M. S.: How widespread and important is $\mathrm{N}_{2}$ fixation in the North Atlantic Ocean?, Global Biogeochem. Cycles., 21, GB4015, doi:10.1029/2006GB002886, 2007.
Riera, P., Stal, L. J., Nieuwenhuize, J., Richard, P., Blanchard, G., and Gentil, F.: Determination of food sources for benthic invertebrates in a salt marsh (Aiguillon Bay, France) by carbon and nitrogen stable isotopes: importance of locally produced sources, Mar. Ecol. Prog.Ser., 187, 301-307, 1999.

Roy, R.: Short-term variability in halocarbons in relation to phytoplankton pigments in coastal waters of the central eastern Arabian Sea, Estuar. Coast. Shelf. Sci., 88, 311-321, 2010.

Roy, R., Prathihary, A., Mangesh, G., and Naqvi, S. W. A.: Spatial variation of phytoplankton pigments along the southwest coast of India, Estuar. Coast. Shelf. Sci., 69, 189-195, 2006.

Saino, T. and Hattori, A.: ${ }^{15} \mathrm{~N}$ abundance in oceanic suspended particulate matter, Nature, 283, 752-754, 1980.

Saino, T. and Hattori, A.: Geographical variation of the watercolumn distribution of suspended particulate nitrogen and its ${ }^{15} \mathrm{~N}$ natural abundance in the Pacific and its marginal seas, Deep-Sea Res., 34, 807-827, 1987.

Schäfer, P. and Ittekkot, V.: Isotopic biogeochemistry of nitrogen in the northern Indian Ocean, Mitt. Geol.-Palaont. Inst. Univ. Hamburg, 78, 67-93, 1995.

Schefuß, E., Ratmeyer, V., Stuut, J. W., Jansen, J. H. F., and Sinninghe Damste, J. S.: Carbon isotope analyses of n-alkanes in dust from the lower atmosphere over the central eastern Atlantic, Geochim. Cosmochim. Acta., 67, 1757-1767, 2003.

Schott, F. and McCreary, J. P.: The monsoon circulation of the Indian Ocean, Prog. Oceanogr., 51, 1-123, 2001.

Smith, B. N. and Epstein, S.: Two categories of ${ }^{13} \mathrm{C} /{ }^{12} \mathrm{C}$ ratios for higher plants, Plant Physiol. (Bethesda), 47, 380-384, 1971.

Suprit, K. and Shankar, D.: Resolving orographic rainfall on the Indian west coast, Int. J. Climatol., 28, 643-657, 2008.

Van Heukelem, L.: HPLC phytoplankton pigments: Sampling, laboratory methods, and quality assurance procedures, in: Ocean Optics Protocols for Satellite Ocean Color Sensor Validation, edited by: Mueller, J. and Fargion, G., Revision 3, Volume 2, Chapter16, NASA Technical Memorandum 2002-2004, 258268, 2002.

Wada, E. and Hattori, A.: Nitrogen in the sea: Forms, Abundances, and rate processes, CRC Press, Boca Raton, 1991.

Wada, E., Kadonaga, T., and Matsuo, S.: ${ }^{15} \mathrm{~N}$ in nitrogen of naturally occurring substances and global assessment of denitritication from isotopic viewpoint, Geochem. J., 9, 139-148, 1975.

Wada, E., Terazaki, M., Kabaya, Y., and Nemoto, T.: ${ }^{15} \mathrm{~N}$ and ${ }^{13} \mathrm{C}$ abundances in the Antarctic Ocean with emphasis on the biogeochemical structure of the food web, Deep-Sea Res., 34, 829-841, 1987.

Weijers, J. W. H., Schouten, S., Schefuß, E., Schneider, R. R., and Sinninghe Damste' J. S.: Disentangling marine, soil and plant organic carbon contributions to continental margin sediments: A multi-proxy approach in a 20,000 year sediment record from the Congo deep-sea fan, Geochim. Cosmochim. Acta., 73, 119-132, 2009. 